\title{
THE STUFF OF LEGEND: HISTORY, MEMORY, AND THE TEMPORALITY OF ORGANIZATIONAL IDENTITY CONSTRUCTION
}

\author{
DAVIDE RAVASI \\ University College London \\ VIOLINA RINDOVA \\ University of Southern California, Los Angeles \\ ILEANA STIGLIANI \\ Imperial College London
}

\begin{abstract}
A growing body of research on how organizations engage with their histories has shown that organizational members revisit history in the light of present-day concerns to inspire or legitimize future courses of action. Studies of the processes through which organizational history is brought to bear on the present and future, however, remain rare. To uncover the processes and practices through which organizational members systematically engage with history, we investigate uses of material memory in four corporate museums. Our analysis uncovers three distinct modes of engagement, reflecting different temporal perspectives on organizational identity, involving different cross-temporal interpretative processes, and influencing action in different ways. Our theoretical insights have significant implications not only for understanding the use of history in organizations, but also for research on organizational identity and organizational memory.
\end{abstract}

There are times in the history of companies ... when it is necessary to stop and think about the road we have traveled. In this way, not only do we refresh our memories, make room for nostalgia, and evaluate our triumphs and our mistakes, we also understand the value of what we have done, make sense of our actions, and draw inspiration and a new impetus for the future. (Chairman, Piaggio, 2003)

Historians adopting a constructivist view (Cox \& Stromquist, 1998) distinguish between the "past" as a set of events and experiences, and "history" as a partial and subjective reconstruction, ordering, and framing of these events and experiences (Lowenthal,

The authors would like to thank associate editor Scott Sonenshein and three anonymous reviewers for their insightful comments regarding previous versions of this manuscript. We are also grateful to our interviewees from the four organizations, and, in particular, would like to thank Francesca Appiani, Lorenzo Ardizio, Sabrina Caredda, Tommaso Fanfani, Marco Lambri, Livio Lodi, Marco Montemaggi, and Pasquale Oliveri for having enthusiastically supported our research and for all of the precious time that they have dedicated to us over the years.
1985). Consistent with this idea, sociological research has begun to examine collective practices through which people constitute selective reconstructions of the past as "collective memory," making them relevant to their lives and identities in the present (e.g., Olick \& Robbins, 1998; Zerubavel, 1996).

Building on this work, organizational scholars have begun to study how organizations use history as a resource to legitimize and inspire present-day actions, such as (re-)building understandings of the organizational identity (Ravasi \& Schultz, 2006; Schultz \& Hernes, 2013), legitimizing new strategic initiatives (Hatch \& Schultz, 2017; Sasaki, Kotlar, Ravasi, \& Vaara, 2019), and crafting narratives to increase product appeal (Foster, Suddaby, Minkus, \& Wiebe, 2011).

In line with the idea that "the materials out of which [the] past is constructed lie in the present" (Mead, 1932: 29), these studies have focused on historical artifacts as a material form of memory (Schultz \& Hernes, 2013) that helps with forging interpretative links between the past, present, and future of an organization (Hatch \& Schultz, 2017; HowardGrenville, Metzger, \& Meyer, 2013). However, the 
accounts they offer of how members use history and material memory to inform present-day action remain incomplete and, at times, inconsistent.

Some studies, for instance, emphasize strategic intentionality in engaging with history and memory (Nissley \& Casey, 2002; Suddaby, Foster, \& Quinn Trank, 2010), and highlight the purposeful manipulation of historical narratives to selectively emphasize events that support a desired image (Foster et al., 2011; Rowlinson \& Hassard, 1993). Others describe the process as a serendipitous "rediscovery" and reuse of historical artifacts to increase the perceived "authenticity" of new practices, and draw attention to the "emotional resonance" that triggers the process (Hatch \& Schultz, 2017). The evidence that organizational members engage with history and memory, therefore, is growing, but the processes through which they do so remain poorly understood.

Understanding these processes is important because the past always evokes multiple interpretations, and the ones chosen affect both individual and organizational courses of action (Kaplan \& Orlikowski, 2013). As Flaherty and Fine (2001: 151) noted, "the past confronts the present with an array of facts, but the effects of these facts are mediated by attention and interpretation, which render their actual impact uncertain.” Therefore, specifying the processes through which the past is brought to bear on the present is critical to advancing organizational knowledge on of how and why organizations use their history.

To shed new light on this question, we conducted a qualitative, theory-building study in relation to four corporate museums at Alessi, Alfa Romeo, Ducati, and Piaggio. Our analysis unpacks the process though which members use material memory to construct historicized understandings of organizational identity (Albert \& Whetten, 1985), and use these understandings to inform their decisions and actions. In the four cases we studied, members used historical artifacts to support performing a broad range of tasks related to product innovation, brand communication, and human resource (HR) management. Depending on the primary audience that they associated with their tasks, members engaged with history and identity in different modes, which we termed identity stewardship, identity evangelizing, and heritage mining. These modes therefore were not organizationspecific, but task-related: across the four cases, members who engaged in similar tasks displayed similar modes of engagement.

The three modes reflected the fact that organizational members in different roles prioritized differently what Whetten (2006) called "definitional standards" of organizational identity-namely, centrality, enduringness, and distinctiveness. Each mode involved different cross-temporal sensemaking processesunderstood as interpretive processes of selecting and connecting cues from different moments in time to construct identity understandings-and bore different implications for organizational action.

The theoretical insights emerging from our study illuminate the processes through which the past (in the form of history and memory) is brought to bear on the present (identity understandings) and the future (organizational action), with important implications for our understanding of how members use material memory to reconstruct history and identity to inform novel action. These findings encourage us, more generally, to revisit widely held assumptions about how organizational identities are constructed and how memory processes shape action.

\section{THEORETICAL BACKGROUND}

\section{The Use of History in Organizations}

Early studies of organizational storytelling emphasized how narratives about past events contribute to (re-)producing shared understandings of an organization (Boje, 1995; Martin, Feldman, Hatch, \& Simkin, 1983). This work laid the foundation for a narrative view of organizational memory (Rowlinson, Casey, Hansen, \& Mills, 2014), bringing attention to how organizational leaders revisit historical accountsoften sacrificing their accuracy and comprehensiveness-to lend historical credibility to current claims about organizational values and practices (Rowlinson \& Hassard, 1993).

Research on organizational identity similarly recognized that history is periodically reconstructed to promote a desired identity (Gioia, Corley, \& Fabbri, 2002; Gioia, Schultz, \& Corley, 2000). This work questioned the idea of enduringness as one of the three definitional standards of organizational identity, and highlighted instead the proactive reconstruction of history as a key process for maintaining a sense of continuity in "who we are" amid change (Gioia et al., 2000).

Building on these ideas, Suddaby and colleagues introduced the notion of "rhetorical history" to highlight the selective interpretation of the organizational past purposefully designed to "valorize the corporation and advance its purposes" (Suddaby et al., 2010: 161), legitimize its current strategies, and maintain the appearance of stability and continuity in the face of change (see also Maclean, Harvey, 
Sillince, \& Golant, 2014). They portrayed history as a rhetorical resource, subject to strategic control by senior managers, that periodically undergoes reconstructions ranging from sanitized chronologies to entirely new narratives created by marketing departments. Consistent with these arguments, a study of the coffee chain Tim Hortons exemplified how organizations use historical narratives to forge a symbolic link between the organizational identity, collective memories, and enduring societal values (Foster et al., 2011). Hatch and Schultz (2017) similarly observed how managers at the Danish brewer Carlsberg drew inspiration from an old corporate motto engraved on a factory wall to enhance the perceived authenticity of a new line of premium beer, and, later, to articulate a new corporate philosophy and vision.

Recent studies have shifted attention from the content of historical narratives to the question of how these narratives are produced in the first place, and have begun to examine mnemonic practices in organizations - that is, practices through which members remember the organizational past by maintaining or revising historical accounts. This research suggests that the scope and depth of the historical accounts that organizational members produce is influenced by the range of oral, textual, and material memory forms they draw upon (Schultz \& Hernes, 2013). It has also shown that organizations can strategically use material artifacts-as "physical signs of history" (Ooi, 2002: 607)—in the production of preferred historical accounts (e.g., Anteby \& Molnar, 2012; Nissley \& Casey, 2002).

Collectively, these studies provide resounding support for the idea that organizations use their history as a resource. Past research, however, offers only partial and partly inconsistent understandings of the processes through which organizational members use this resource to construct courses of actions. For example, the occasional and serendipitous engagement with historical artifacts that Hatch and Schultz (2017) described contrasts with the deliberate collection, assembly, and display of such artifacts associated with corporate museums (Nissley \& Casey, 2002). The rhetorical use of history to stimulate identification (Suddaby, Foster, \& Quinn Trank, 2016) is also somewhat inconsistent with its substantive use to ensure continuity in times of strategic change (Ravasi \& Schultz, 2006). To guide our systematic investigation of the processes through which organizational members engage with history, we turned to the theoretical apparatus developed by sociological research on social memory and collective practices of remembrance (Olick \& Levy, 1997; Zerubavel, 1996).

\section{History, Collective Memory and Identity in Social Memory Studies}

Social memory studies examine how the past is actively incorporated in identity and action through practices of remembrance (and forgetting) that constitute and alter collective memory-understood as socially maintained representations of the past that have relevance to the collective identity of a community (Assmann, 1995; Olick, 1999; Zerubavel, 1996). Two key insights from this research are relevant to our study. First, these studies suggest that engagement with history through mnemonic practices, such as collecting historical artifacts, commemorating events, and visiting memory sites, are key mechanisms for making history relevant to people's lives (Nora, 1989; Olick \& Levy, 1997). Collective memory, therefore, is not "a thing" (Olick \& Robbins, 1998: 112) but a process (Wagner-Pacifici \& Schwartz, 1991; Zolberg, 1996) through which people "get in touch with history" (Barthel, 1996: 345). Material culture is seen as central to mnemonic practices, as "remembering is something which occurs in a world of things, as well as words" (Radley, 1990: 57-58).

Second, building on Halbwachs's (1925/1992) early insights that shared memories serve as powerful markers of social differentiation, Zerubavel (1996) has argued that remembering a collective past is a process of "mnemonic socialization," defined as the acquisition of collective memory as one's own. Through mnemonic socialization, members of a group come to agree on a particular view of a common past, and a collective, historically embedded identity (Wertsch, 2002). A social group's cohesion and collective identity, social memory studies argue, depend on its strength as a mnemonic community, defined by shared representations of past events (only some of which members have experienced personally). Mnemonic socialization is central to the maintenance of this community.

By emphasizing the importance of mnemonic practices through which history becomes collective memory, sociological research shifts the analysis from sporadic engagements with history to ongoing practices that systematically invoke history to maintain a collective identity. Taking our lead from this approach, we focused our study on understanding how the ongoing engagements with the past afforded by the historical artifacts displayed in corporate museums influenced how members made sense of their organizations' identities and defined "useful line(s) of action" for the future (Flaherty \& Fine, 2001: 152). 


\section{METHODS}

\section{Research Setting}

We conducted our study in four corporate museums-facilities designed to collect and display organizational artifacts illustrating the organization's history and operations to employees, customers, and other visitors (Danilov, 1992). Anecdotal evidence exists that corporate museums support internally and externally oriented activities, ranging from HR management to corporate communication, design and branding (Dumiak, 2006; Schumpeter, 2012). Corporate museums, therefore, represent ideal sites for observing systematically how organizational members engage with an organization's history (Yin, 1994).

We began our search for case sites by contacting the national association of corporate museums in Italy. Two of the four museum curators who sat on its board-from Alessi and Piaggio-agreed to provide us with sufficient access to multiple data to support robust case analysis. Alessi is a producer of kitchenware; its products are designed by highly regarded artists, industrial designers, and architects, and are displayed in modern art museums around the world. Piaggio is one of the world's largest producers of light vehicles and the maker of the iconic Vespa scooter. We asked our initial informants to suggest other organizations that could help us deepen our inquiry, using a "snowballing" technique appropriate for sampling in a relatively unexplored setting (Miles \& Huberman, 1984: 28). Based on their suggestions, we gained access to two more sites: Alfa Romeo and Ducati. At the time of our study, Alfa Romeo, formerly an independent carmaker with a notable history in car racing, was a division of FIAT Automobiles; and Ducati was an independent producer of high-end motorcycles with an active racing team (later acquired by Audi AG). Table 1 provides further comparative information regarding our research sites.

\section{Data Collection}

In-depth semi-structured interviews were our main data source. We selected informants through theoretical sampling (Locke, 2001: 54-55), starting with museum curators and other staff members, and moving to senior managers in various functional areas, employees who regularly used the museum, and outsiders (e.g., external designers and members of fan clubs) whom informers identified as relevant users. At Ducati and Alessi, we interviewed the chief executive officers (CEOs) who had authorized the development of the respective museums; at Piaggio and Alfa Romeo, the founders of the museums were no longer alive, so we interviewed other members of the senior management team who were involved in museum activities. In total, we conducted 59 interviews with 47 informants (see Table 2 for an overview of our interviews). Interviews lasted between one and two hours, on average, and were all recorded and transcribed. They initially followed a common protocol, which, consistent with prescriptions for qualitative research (Graebner, Martin, \& Roundy, 2012), evolved to incorporate emerging insights.

We supplemented our interview data with multiple archival sources (see Table 2). In a preliminary phase, we accessed museum websites for historical information about the company and the museum. The four museums also maintained archives, which they made available during the visits. Informants also shared with us public speeches of museum curators and other managers, templates for guided visits, press articles, corporate brochures, corporate biographies, house magazines, and other internal documents. Initially, we used archival sources to familiarize ourselves with our research setting. Later on, we used them to corroborate informants' reports, and document the impact on actions associated with each engagement mode. During the museum visits, we also took field notes about the physical setting, objects displayed, and visitors observed (Yanow, 1998). These observations, along with informal conversations with interviewees during the visits, served to enrich our understanding and stimulate "creative insight" (Suddaby, 2006).

\section{Data Analysis}

Our analysis combined procedures for grounded theory (Charmaz, 2014; Locke, 2001) and case analysis (Eisenhardt \& Graebner, 2007) to produce rich insight into our object of study. The analytical process was highly iterative, involving multiple rounds of coding and traveling back and forth between emerging themes, relevant literature, and the data.

Step 1. Mapping users and uses of corporate museums as memory sites. We began our analysis by creating historical accounts about how and why each museum was established, who was involved in the founding, and where the collection came from. We then mapped systematically who accessed and used the museum collections (e.g., HR managers, designers, etc.), how, and why. We conducted this analysis early on, largely relying on interviews with the museum staff, supplemented by archival records 

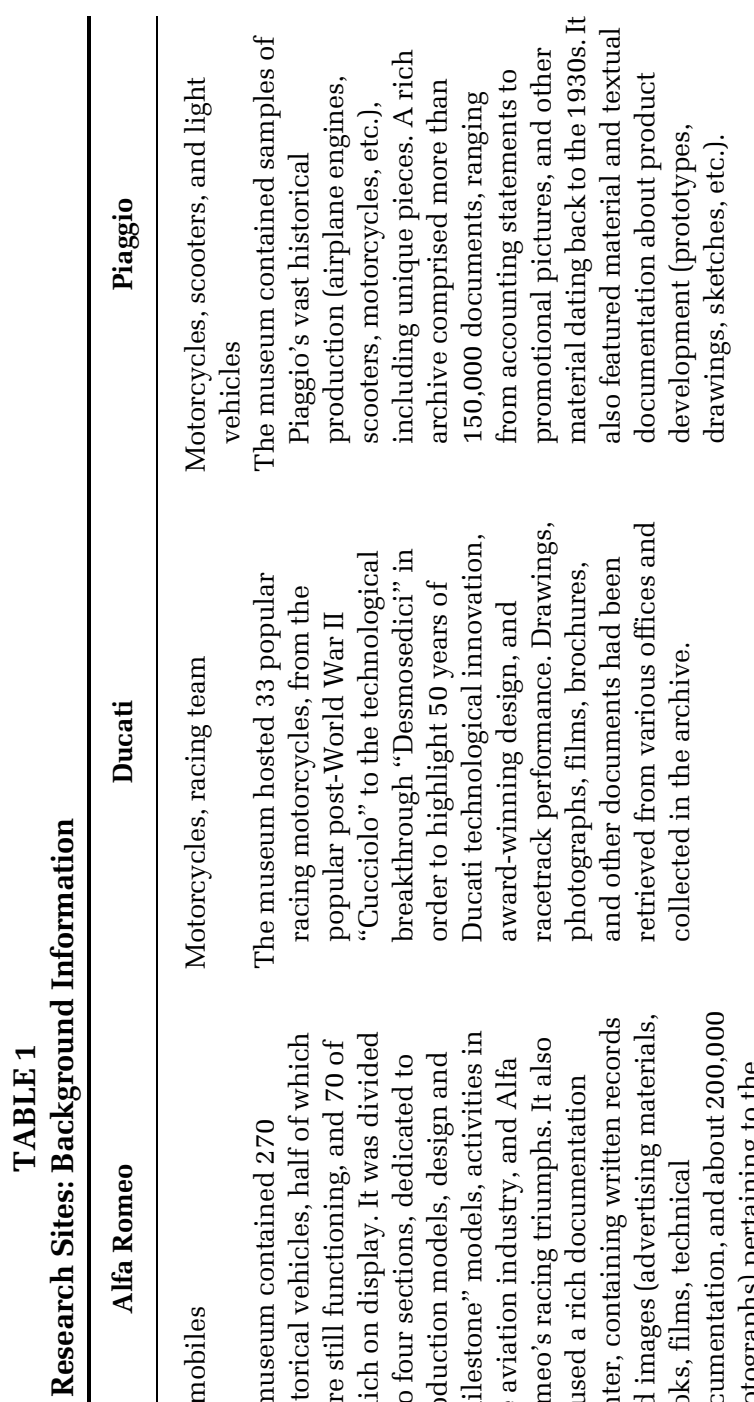

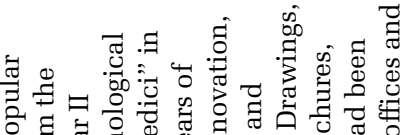

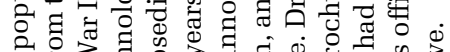

焉

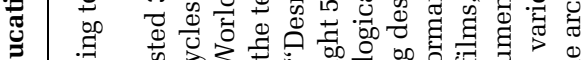

o

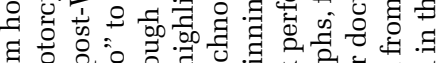

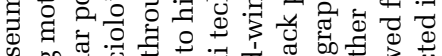

o

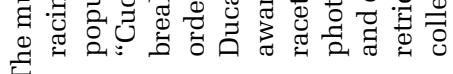

궁 范

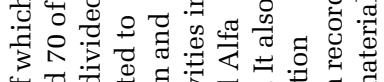

吾

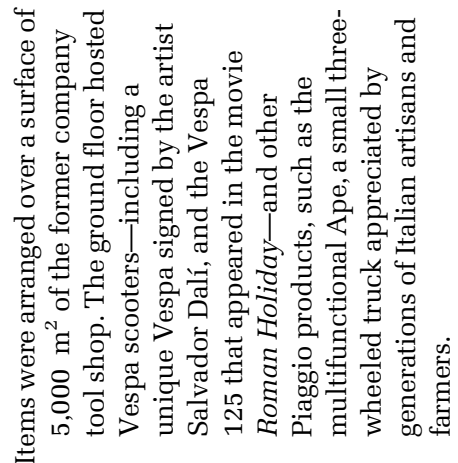

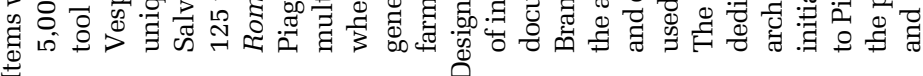

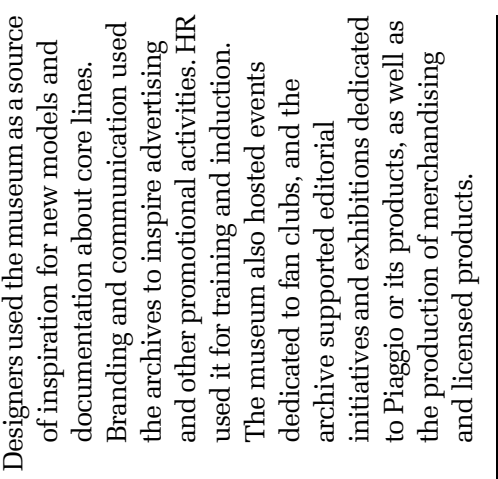

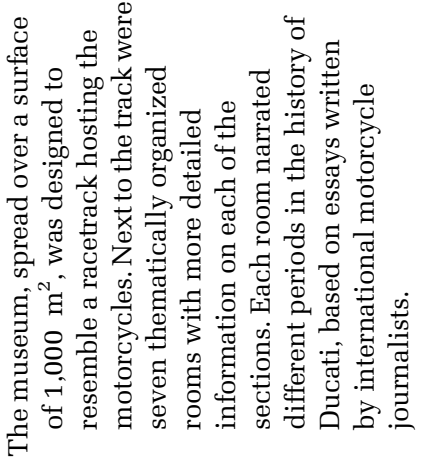

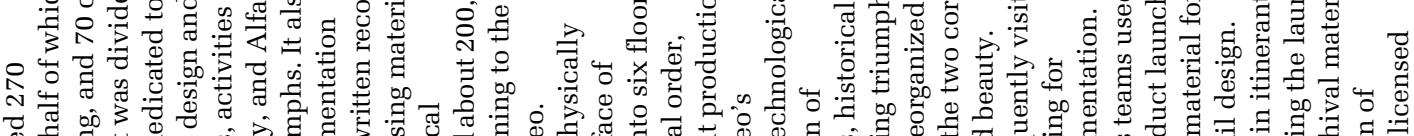
出

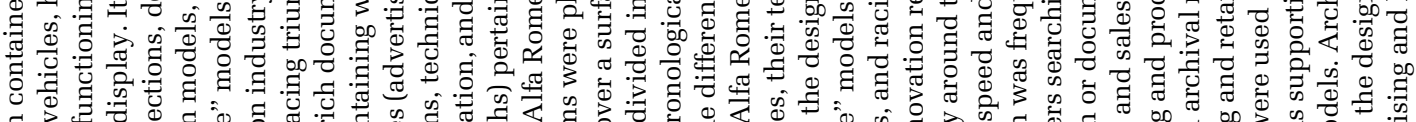

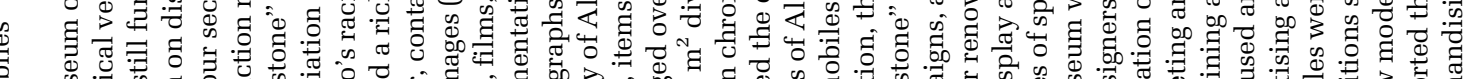

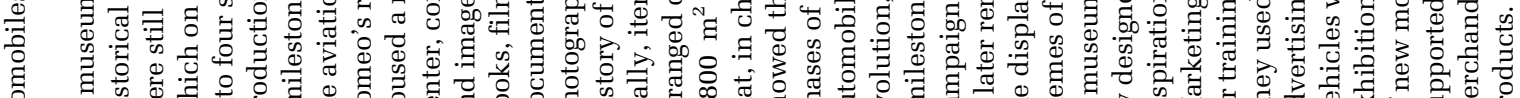

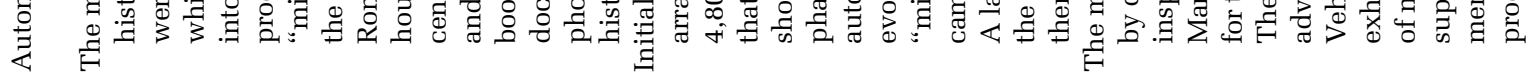

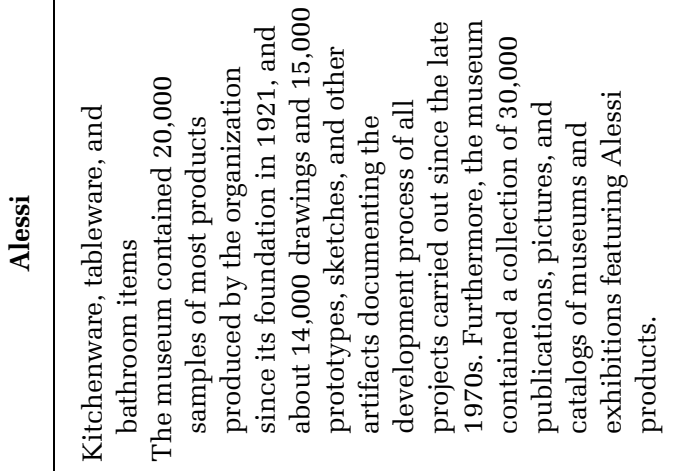

.

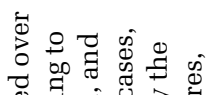

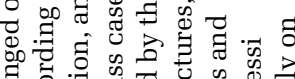

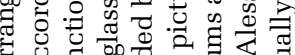
ส

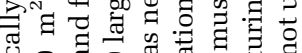

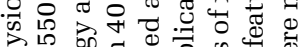
द्व

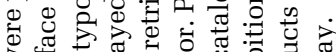

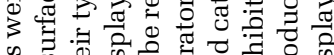

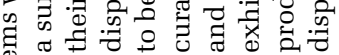

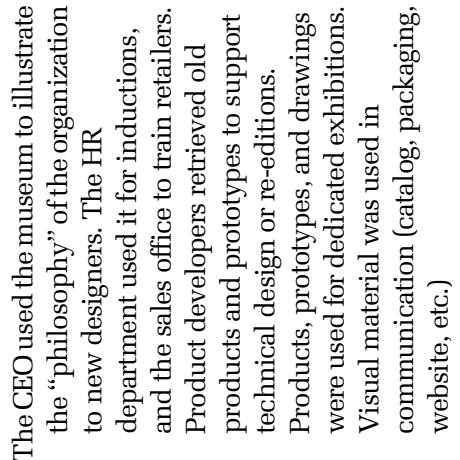

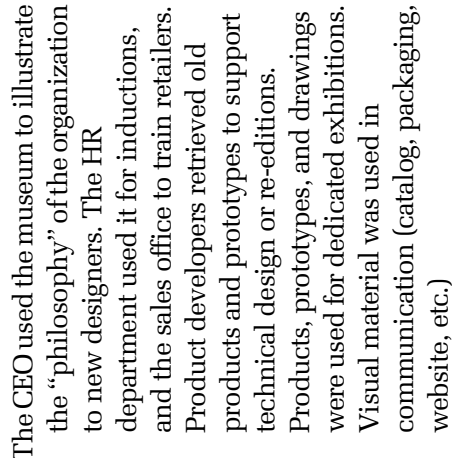

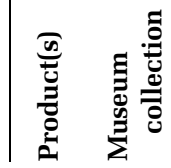




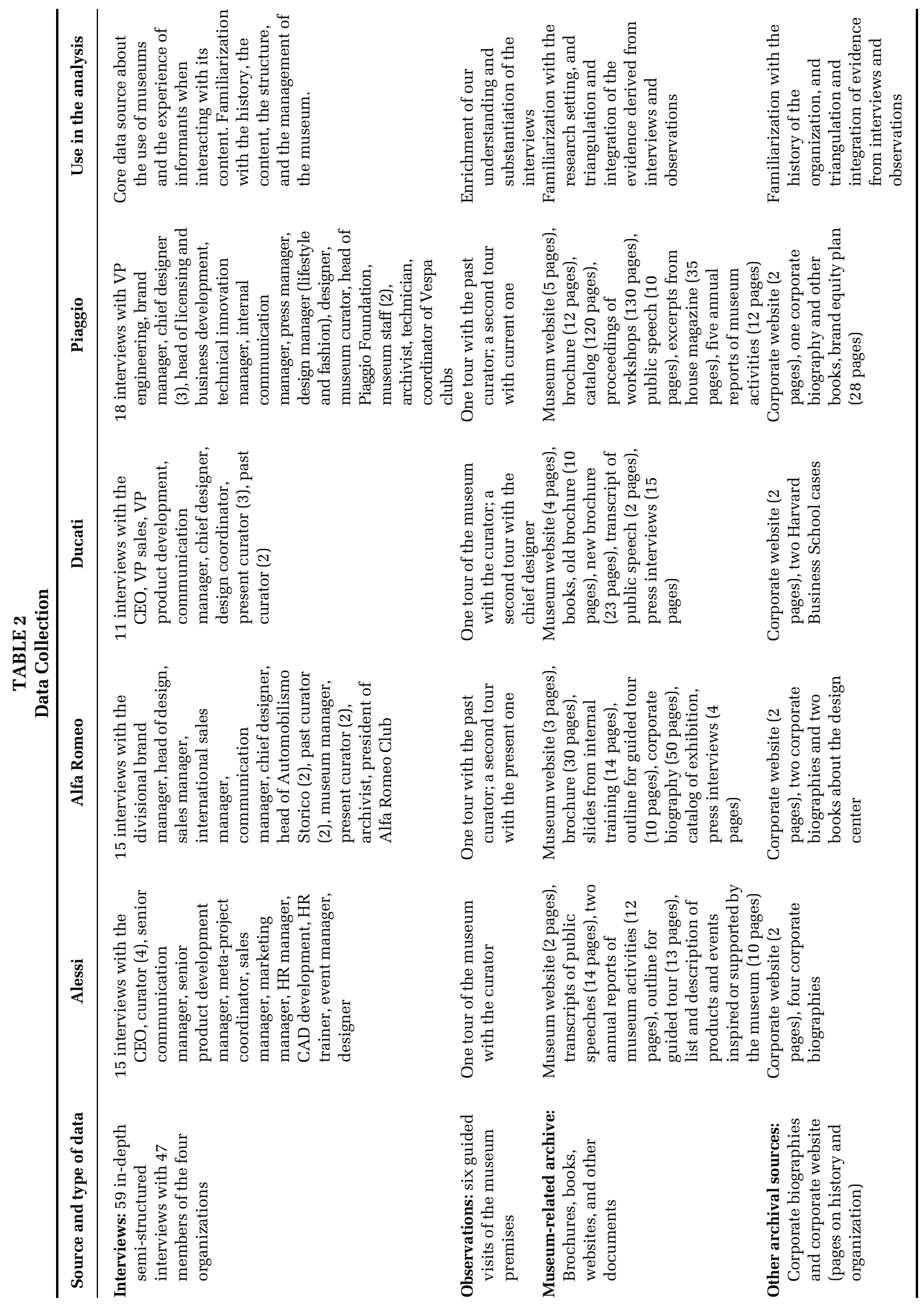


that some of them kept. We refined the analysis through subsequent interviews, as different informants shared examples of various occasions of museum use, providing evidence that their engagements were not occasional but systematic and reflective of their needs to make and give sense about distinguishing attributes of their organizations.

Step 2. Coding the uses and interpretations of historical artifacts. Next, we turned to an open coding of textual data to produce a grounded analysis of the processes associated with museum uses. To this end, all three researchers searched available data for relevant phrases and passages describing examples of museum uses. We initially coded these passages with in vivo terms and phrases used by interviewees (Locke, 2001: 65), and then combined those that had similar meanings into more abstract first-order codes. For instance, we initially used in vivo codes to label fragments referring to the museum collections being used to express the "essence," "distillate," or "soul" of the organization, and eventually grouped them into a firstorder code "emphasis on centrality." Similarly, we combined fragments referring to the collections being used to preserve the "tradition" or "legacy" into the first-order code "emphasis on enduringness." In a subsequent coding step, we aggregated these first-order codes into a broader, second-order construct; namely, "prioritization of identity definitional standards." We used these second-order constructs as building blocks for our grounded model. Consistent with prescriptions for grounded theory, data collection and analysis across cases partly overlapped, as we engaged in the preliminary coding of data about two cases while data collection in the other two was still in progress.

Step 3. Comparative coding across cases and informants. As we moved from open to axial coding and explored relations among our codes, we initially produced a tentative organization-level framework highlighting common patterns across the four cases. A further round of data collection, however, suggested that this model obscured important variation in how organizational members in different roles used material memory to makes sense of distinguishing features of their organization. Following this realization, we recoded the data to unpack this variation. These analyses revealed that, across organizations, informants in similar roles displayed similar patterns, which we termed "modes of engagement with history and identity" (hereafter, for brevity, "engagement modes").

We labeled the three modes "identity stewardship," "identity evangelizing," and "heritage mining." Members in the first mode searched for distinctiveness in the historical consistency of technological and aesthetic features of past products, and pursued continuity of these features when developing future products. Members in the second mode searched for distinctiveness in essential qualities and values, abstracted from historical artifacts associated with past accomplishments, and claimed their relevance in the present. Members in the third mode searched for distinctiveness in any element of a unique past that could be referenced symbolically to enhance the appeal of new offerings, outside the regular product lines. In a further round of coding, to uncover an explanation for the variation we observed, we examined how informants motivated their actions and uncovered the influence of primary referent audiences on informants' task-related uses of historical artifacts. Through these multiple rounds of analysis, our key constructs and grounded model emerged.

To combine the emerging constructs in a theoretical model, we followed a strategy for process theorizing that Langley (1999) referred to as "synthetic": first, through axial coding (Strauss \& Corbin, 1998: 123), we assembled the emerging conceptual categories in a process model theorizing how organizational members use material memory to construct historicized, taskrelevant identity understandings; second, we used our comparative analysis to uncover and explain the observed variance in how the process unfolded in different situations-in our cases, the three engagement modes displayed by informants in different roles. We discussed our emergent insights and model with colleagues and key informants to perform ongoing validity checks on our interpretations (Corbin \& Strauss, 1990).

Step 4. Relating modes of engagement to action. In a final analytical step, we searched our archival data for evidence of the influence of the three engagement modes on how informants performed their tasks. Examples offered by informants primarily associated with each mode guided our archival search. To document the influence of identity stewardship, for example, we searched for evidence of pursued continuity of traditional stylistic or technological features in vehicles produced by Alfa Romeo, Ducati, and Piaggio (with a focus on the Vespa lines). To document influence of identity evangelizing, we sought examples of how promotional events (exhibitions, product launches, gatherings, etc.) and communication material, including the design of the museums themselves, used commemorations of the past to express distinctive values. To document the influence of heritage mining, we searched for uses of historical symbolism in merchandising, licensed products, and special or limited editions. In this step, we refined our theorization of the three modes, and established their consequentiality for organizational action. 


\section{FINDINGS}

Across all four organizations, informants viewed the historical artifacts exhibited in the museums as a material form of memory that supported the performance of tasks ranging from the development of new products or brand policies to the induction and training of new recruits. These tasks, informants explained, required them to make sense of what distinguished their organization from competitors. They sought answers to this question in their organization's past, and used historical artifacts to construct understandings of the organizational identity that were instrumental to the performance of their tasks. The curatorial choices that constituted museum collections defined the context within which they did so, but the distinct engagement modes they employed shaped the different ways in which they constructed these understandings.

Our analysis uncovered three distinct modes that members adopted, depending on the construed concerns and expectations of the audiences their task involved (primary referent audiences) and the identity definitional standards that these expectations led them to prioritize. The three modes-identity stewardship, identity evangelizing, and heritage mining-differed in how members interpreted the relevance of organizational history to their present-day understanding of organizational identity (temporal perspectives on organizational identity), how they used historical artifacts to link history to identity (interpretative use of artifacts), and the interpretative links they made along the temporal dimension of past, present, and future (cross-temporal sensemaking). Figure 1 visualizes these processes and highlights differences in how they manifest in each mode. It shows the situational embeddedness of these processes in the context of specific tasks (indicated by the lighter shaded area), and their link to material memory constituted through the preservation and display of historical artifacts. Finally, Figure 1 connects the overall process of constructing task-relevant historicized identity understandings to organizational action. Tables 3 to 6 summarize the theoretical ideas and evidence supporting the model depicted in Figure 1, with Table 3 summarizing differences across the three modes, and Tables 4, 5, and 6 providing select evidence about each mode.

\section{Identity-Related Tasks and the Need for Task-Relevant Identity Understandings}

Not all organizational members engaged with the museums and their collections on a regular basis.
Those who did tended to hold positions with responsibility for either presenting the organization to internal and external audiences (e.g., through communications or product design) or coordinating such presentations (e.g., CEOs and brand managers). These regular museum users consistently described their tasks as requiring them to make or give a sense of what distinguished their organization from competitorswhat they called its "uniqueness" or "peculiarity."

To do so, they searched in the organizational history for inspiration and support for their reflections on appropriate future actions. The chief designer of Piaggio summarized this sentiment as follows: "We cannot design our future, if we don't know our past. You need to know who you are to figure out what you want to become." A sales manager at Alfa Romeo echoed this point, saying, "It is important to be aware of what you have been in order to look at the future and propose yourself with distinctiveness." We refer to the understandings that members constructed in these situations as "historicized," because they reflected the adoption of a historical frame of reference (Whetten, 2006) to make and give a sense of the identity of the organization, and act accordingly.

According to Whetten (2006), when assessing the appropriateness of their action, organization members may adopt a comparative frame of reference, and act in accordance with conventional expectations for organizations of the same type, or a historical one, prompting them to act consistently with a history of strategic choices and commitments. A historical frame of reference is typically invoked in situations, such as those our informants described, when members are expected to claim a "unique social space" by establishing the "distinguishing organizational practices, competencies, and traits, including organizationspecific attributes of members, products, and services" that differentiate their organization from competitors (Whetten, 2006: 222, 225). ${ }^{1}$ We refer to these situations as "identity-related" tasks, and we visualize them in Figure 1 as the context within which the processes we observed unfolded.

\footnotetext{
${ }^{1}$ Our argument here does not imply that the adoption of a historical frame negates the utility of a comparative one. In other words, it is not the case that being a "producer of motorcycles" (a type of organizations) does not matter for Ducati, or that being a "family firm" does not matter for Alessi. In ordinary circumstances, however, these comparative frames are usually taken for granted, and less likely to be salient to decisions made by members in their capacity of designers, brand managers, and so on, unless they can be used to positively distinguish the organization from competitors.
} 
FIGURE 1

Material Memory and the Construction of Historicized Organizational Identity Understandings

ORGANIZATIONAL PAST

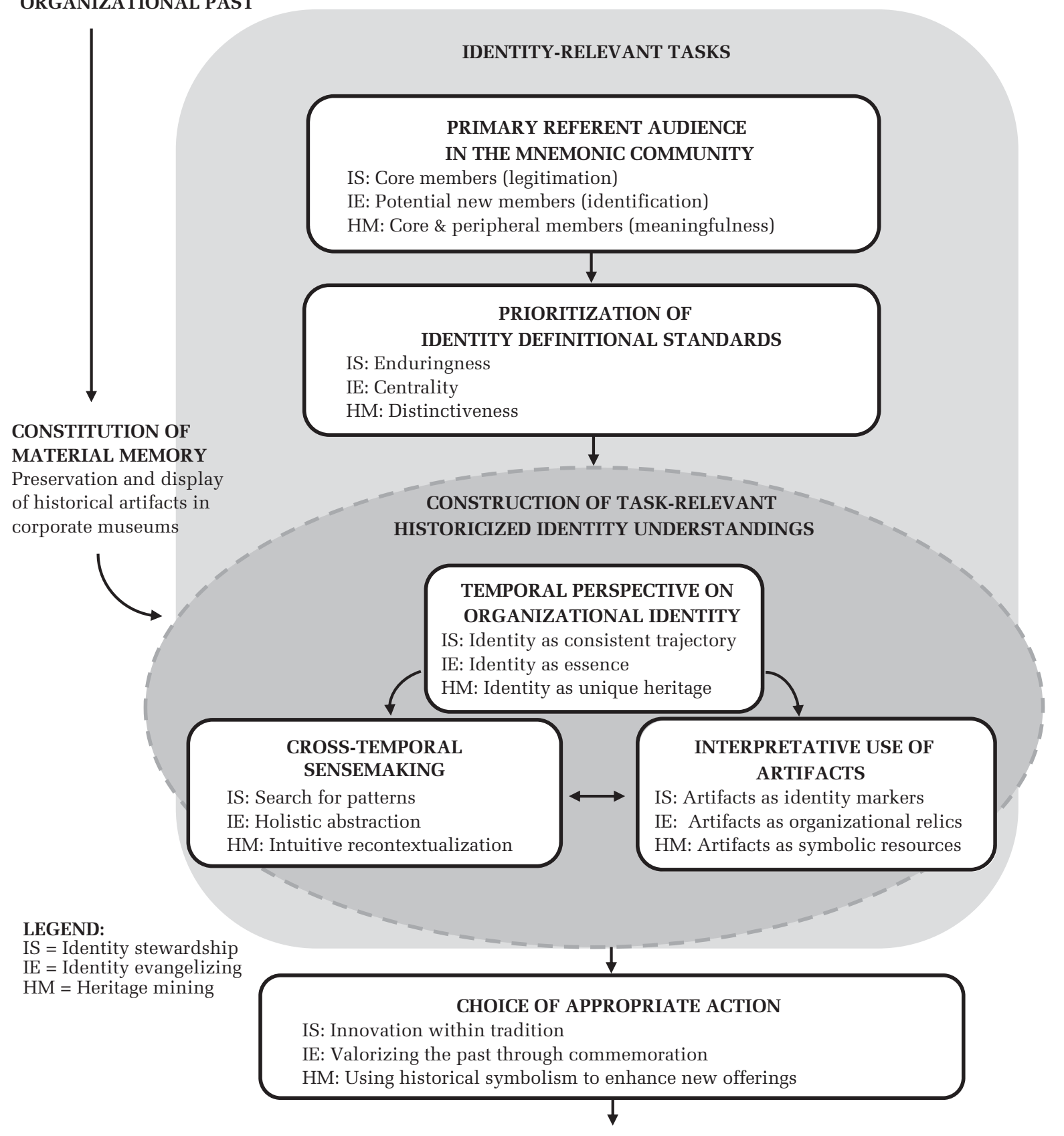

ORGANIZATIONAL FUTURE

We refer to the identity understandings that members produced in these circumstances as "task relevant" because they were not necessarily widely shared within the organization, but instrumental to the performance of the task. They can be conceptualized as situated cognitions; that is "transitory perceptual frameworks [that] enable one 'to comprehend, understand, explain, attribute, extrapolate, and predict' (Starbuck \& Milliken, 1988: 51) and, additionally (and crucially), to act within a very specific situational context" (Elsbach, Barr, \& Hargadon, 2005: 424). Figure 1 visualizes these 
TABLE 3

Modes of Engagement with History and Identity: A Theoretical Summary

\begin{tabular}{|c|c|c|c|}
\hline & Identity stewardship & Identity evangelizing & Heritage mining \\
\hline $\begin{array}{l}\text { Task-relevant primary referent } \\
\text { audience }\end{array}$ & $\begin{array}{l}\text { Maintaining legitimacy with } \\
\text { core members of the } \\
\text { mnemonic community. } \\
\text { Emphasis on conformity of } \\
\text { novel action with collective } \\
\text { expectations for continuity. }\end{array}$ & $\begin{array}{l}\text { Identification of new members } \\
\text { of the mnemonic community. } \\
\text { Emphasis on inducing or } \\
\text { reinforcing identification } \\
\text { based on congruence between } \\
\text { individual and organizational } \\
\text { values. }\end{array}$ & $\begin{array}{l}\text { Significance for peripheral } \\
\text { members of the mnemonic } \\
\text { community. Emphasis on } \\
\text { infusing novel action with } \\
\text { significance because of } \\
\text { symbolic connections } \\
\text { between the organizational } \\
\text { past and personal memories } \\
\text { and imagery. }\end{array}$ \\
\hline $\begin{array}{l}\text { Prioritization of definitional } \\
\text { standard and temporal } \\
\text { perspective on organizational } \\
\text { identity }\end{array}$ & $\begin{array}{l}\text { Prioritization of enduringness } \\
\text { (vs. centrality) to support } \\
\text { claim of continuity of } \\
\text { distinctive action. "Who we } \\
\text { are" understood primarily in } \\
\text { terms of the continuity of } \\
\text { features that distinguished } \\
\text { organizational actions in the } \\
\text { past (identity as consistent } \\
\text { trajectory). }\end{array}$ & $\begin{array}{l}\text { Prioritization of centrality (vs. } \\
\text { enduringness) to support the } \\
\text { coherent expression of } \\
\text { distinctive values. "Who we } \\
\text { are" understood primarily in } \\
\text { terms of essential qualities and } \\
\text { values that distinguish the } \\
\text { organization (identity as } \\
\text { essence). }\end{array}$ & $\begin{array}{l}\text { Focus on distinctiveness (neither } \\
\text { centrality nor enduringness is } \\
\text { a concern). "Who we are" } \\
\text { understood primarily in terms } \\
\text { of a multitude of historical } \\
\text { artifacts and meanings that are } \\
\text { unique to the organization and } \\
\text { still significant in the present } \\
\text { (identity as unique heritage). }\end{array}$ \\
\hline Cross-temporal sensemaking & $\begin{array}{l}\text { Search for intertemporal } \\
\text { patters. Focus on prior } \\
\text { outcomes of the focal task; } \\
\text { analytical search for } \\
\text { intertemporal similarities } \\
\text { among cues, to infer enduring } \\
\text { features that can be used to } \\
\text { give sense of continuity in } \\
\text { action. }\end{array}$ & $\begin{array}{l}\text { Holistic abstraction of essential } \\
\text { qualities. Focus on artifacts } \\
\text { associated with past } \\
\text { achievements; search for } \\
\text { atemporal similarities among } \\
\text { cues, to infer abstract qualities } \\
\text { that positively distinguish the } \\
\text { organization from } \\
\text { competitors. }\end{array}$ & $\begin{array}{l}\text { Intuitive recontextualization. } \\
\text { Broad exposure to historical } \\
\text { artifacts; intuitive search for } \\
\text { contemporary relevance of } \\
\text { historical artifacts, to be } \\
\text { reused in a different context to } \\
\text { increase the appeal of new } \\
\text { products or initiatives. }\end{array}$ \\
\hline $\begin{array}{l}\text { Interpretive use of historical } \\
\text { artifacts }\end{array}$ & $\begin{array}{l}\text { Identity markers. Valued as } \\
\text { signposts of trajectories; used } \\
\text { as cues to reconstruct } \\
\text { retrospectively distinctive } \\
\text { longitudinal patterns of } \\
\text { consistent action. }\end{array}$ & $\begin{array}{l}\text { Organizational relics. Valued } \\
\text { for their unique object history, } \\
\text { as tangible links to events or } \\
\text { people that marked distinctive } \\
\text { collective achievements. }\end{array}$ & $\begin{array}{l}\text { Symbolic resources. Valued for } \\
\text { their potential to evoke } \\
\text { associations that can make an } \\
\text { object or an initiative more } \\
\text { appealing for the intended } \\
\text { audience. }\end{array}$ \\
\hline
\end{tabular}

understandings as aggregate outcomes of the interpretative processes associated with engagement modes and organizational actions.

\section{Prioritization of Definitional Standards and Temporal Perspectives on Identity Construction}

Organization scholars generally accept that the features that constitute the organizational identity will be central, enduring (or continuous), and distinctive (Albert \& Whetten, 1985; Gioia, Patvardhan,
Hamilton, \& Corley, 2013). Whetten (2006) characterized these three properties as "definitional standards" for identity. Distinctiveness, he argued, is essential to identity because it positions an organization within a social space, defined by a combination of categorical memberships and differentiating features (see also Navis \& Glynn, 2010). Centrality and enduringness increase the likelihood that a feature is considered by members when reflecting on what distinguishes the organization. "If something isn't a central and enduring feature of an organization," he 
TABLE 4

Identity Stewardship: Illustrative Evidence

Analytical categories

\section{Prioritization of definitional standard and temporal perspective on organizational identity}

Task-relevant primary referent audience

Cross-temporal sensemaking

\section{Interpretive use of historical artifacts}

\section{Prioritization of enduringness (identity as consistent trajectory)}

We cannot design our future, if we don't know our past. You need to know who you are to figure out what you want to become. You need to know your strengths and your origins, how you arrived here today, and the evolution and the intentions of the past. (Chief designer, Piaggio)

It is self-evident that, if you do not know your past and your history well, you cannot make projects about your future. This is certainly the most important reason for the birth of the museum. (CEO, Alessi)

When I came to work at Ducati a few years ago, I realized that the strength and potential of this company stems from its past. (CEO, Ducati)

[Locating the museum beside the design center] is a way to make sure that young designers can plant their roots in the important collection of historical auto of the company. (Designer, Alfa Romeo; public speech)

Maintaining legitimacy with core members of the mnemonic community

The recognizability of Vespa is tied to its iconography. Icon is a religious term, but, when it comes to Vespa, these religious terms are used ironically inside the company. We call the typical client of the PX model a "fundamentalist," because he does not accept variations. When we had to introduce an automatic gear, we had a problem, because the "fundamentalist" did not what to hear about it. (Technical innovation manager, Piaggio)

From a functional point of view, there is no reason for a bike like this to have two disks, because you can brake very well with only one disk, so there so need to add the cost. But the fan wants two disks. Why he wants it that way is irrelevant: he wants two disks because he has two disks in mind. It is useless to try and tell him that one disk is just the same, because it is an emotional thing; it is difficult to oppose them, so two disks it was. (CEO, Ducati)

Often, ad campaigns are not coherent with the product. In a way, this is right, because you have to be up to date. But, if you are misaligned with what you have been in the past, you risk that those who have always bought Alfa no longer identify with the new products, and buy Audi or BMW. (Head of Automobilismo Storico 1, Alfa Romeo)

\section{Search for intertemporal patters}

The museum is important because, by tracing the evolution of models, you can reconstruct the guiding thread, the underlying logic, and you can develop a concept that preserves certain continuity with the past. (Chief designer, Alfa Romeo)

We designers use [the museum] often to see the vehicles, to study their particulars, to get inspired, and even to avoid mistakes made in the past. (Chief designer, Piaggio)

Showing, on a panel behind a salon car, the gradual evolution of the front part [of a model] until that very car we display, helps [to] give a sense of direct continuity ... Showing that an evolution exists and that you updated yourself while preserving a common denominator is an important step to acknowledge your distinctive elements while continuously evolving them. (Sales manager, Alfa Romeo)

\section{Historical artifacts as identity markers}

I was asked to use "a Vespa color." So, I went to the museum and browsed the archives, and decided that the color that best represented Vespa was a green ... I derived this impression from the fact that the typical colors of all historical Vespas are light pastel colors, neither yellow nor red. They tend to be cold colors, ranging from beige to seawater green ... Eventually, we opted for a bluegrey, metallic hue. It was meant to highlight the origins of Vespa. If you enter the museum, you can see objects like the tram or the plane that are made in aluminum and have a similar color. (Designer, Piaggio)

It is fundamental that the product expresses the idea of the brand ... even with literal references to the history of the brand and the items preserved in the archives ... Another important element is the core design philosophy, in this case of the motorcycles, which together with archival research helps define what in fashion we call "permanent stylistic elements," elements recognizable as if they were a signature, which help associate a certain product to a certain brand, so that they can have very long life cycle-hopefully, eternal. (Design manager, lifestyle and fashion, Piaggio)

The museum is important because, by tracing back the evolution of past cars, we can reconstruct the guiding thread, the underlying logic, and we are able to develop a concept that has a tie with the past, that contains the DNA of an Alfa Romeo. (Chief designer, Alfa Romeo) 
TABLE 5

Identity Evangelizing: Illustrative Evidence

Analytical categories

\section{Prioritization of definitional standard and temporal perspective on organizational identity}

Task-relevant primary referent audience

\section{Cross-temporal sensemaking}

Interpretive use of historical
artifacts

Selected evidence

\section{Prioritization of centrality (identity as essence)}

The museum [is] a distillate of the essence of the company. (Museum curator, Ducati)

[The museum] is truly representative of what Alessi is, through the whole creative effort represented by objects and prototypes. (Product development manager, Alessi)

[The museum is meant] to emphasize the creativity, the innovation of the company, its capacity to be always competitive. (Museum curator, Piaggio)

Identification of new members of the mnemonic community

Working at Alessi in any kind of position means not only to accomplish a set of tasks but also to live, in a way, the "Alessi philosophy." To do that, one needs to be somewhat steeped in this philosophy, so much so that, when a person is brought into the firm, we have a scheduled process in the first few days: there is a visit to the factory, a chat with the assistant to the meta-project, aimed at transmitting the "Alessi thinking," and there is this other important moment, which is the visit to the museum ...

We believe that being able to plunge into this dream factory is a wonderful opportunity for everyone who works at Alessi. To see the products and to hear their stories being told is, in our opinion, an opportunity to contact the Alessi reality not only in today's times but also in the past. It is fundamental in order to provide some training on what Alessi is. That is why instruments such as the museum should be emphasized in order to make the history and the philosophy of Alessi known. (HR manager, Alessi)

The museum was the result of the previous management, who believed in the idea of realizing within the factory a museum structure that could be visited, and would be a way to reinforce the loyalty of the traditional Ducatisti and to create new ones.... From a marketing point of view, here we create new scores of Ducatisti. (Museum curator, Ducati)

The goal was not only to make the fans happy, but to create new ones. The numbers reflect this reality. In 12 months, we had more than 100,000 visitors. The brand will benefit. Because, this way, I did not only bring here the expected audience [of fans], but also people that until yesterday had no interest in automobiles or, even worse, they blindly bought foreign cars, and now they come back ... They leave here enthusiastic, so I have brought luster to the brand. (Museum curator 2, Alfa Romeo)

Holistic abstraction of essential qualities

You are immersed in this pool and you become aware of the liquid you are in. No designer ever comes here to look at each window one by one to be creatively stimulated. More than anything else, it is to see the Alessi world, the Alessi approach. (Museum curator, Alessi)

I believe it is important to feel and breathe the values of a brand, not only to look at them or admire them. Otherwise, a voyeurism of the object prevails; you look at the shapes without appreciating all that's around. (Chief designer, Piaggio)

[The museum is important] for the immediateness of its message. With words, you do not always manage to articulate the values that surround Alessi products. The language of some values is a language that it is difficult to express with words. (HR manager, Alessi)

\section{Historical artifacts as organizational relics}

Thinking that Nuvolari was sitting there, or removing the oil stick with the name of Fangio still written on it ... this is not something you can experience every day. (Head of Automobilismo Storico, Alfa Romeo)

Behind these pieces, there were extraordinary levels of activity and passion. Behind Achille Castiglioni's kettle, there are two years of work and of the architect's passion as well as ours. (CEO, Alessi)

Just looking at the plane engines gives you an idea of the depth ... the inventiveness, the genius ... the will to do better always. (Coordinator of Vespa clubs, Piaggio) noted, "then practically speaking, it isn't likely to be invoked as a distinguishing feature, and thus it falls outside the domain specified for this concept" (Whetten, 2006: 224). Scholars, therefore, commonly consider the three properties as necessary qualifications of identity claims and understandings.
In our context, instead, we surprisingly observed that, when reflecting on distinguishing features of their organization, informants assigned differential importance to these three properties-by prioritizing enduringness (identity stewardship), centrality (identity evangelizing), or neither (heritage mining). 
TABLE 6

Heritage Mining: Illustrative Evidence

Analytical categories

Prioritization of definitional
standard and temporal
perspective on
organizational identity

Task-relevant primary referent audience

Cross-temporal sensemaking

\section{Interpretive use of historical artifacts}

\section{Focus on distinctiveness (identity as unique heritage)}

[Presenting a product at the museum helps] treasure a history that is well known around the world ... It is an asset that can add value to a new product. (Communication manager, Alfa Romeo)

History is a value asset: it becomes the cultural capital that you can draw on to create a whole market. What distinguishes us is that we are faithful to our archive, to our history, also making a philological work. (Design manager, lifestyle and fashion, Piaggio)

Moto Guzzi represents the great Italian motorcycle since 1921. It has made the history of Italian racing in the world and has an extraordinary cultural and historical heritage. (Brand manager, Piaggio)

Significance for peripheral members of the community

We do not consider the museum only a large room full of motorcycles. It is a sort of time machine, where different generations of fans and non-fans can interact. Why different generations? Because visitors range from a five-year-old child whose father gave him a little model of a Ducati as a present, to the Ducati fan who collects Ducatis, to the old retired gentleman who remembers the races of the fifties .. My job is like opening a casket full of family memories and showing them to those who come closer. (Museum curator, Ducati)

When I say "heritage," I mean the world that revolves around Vespas, stories told around Vespas, stories that people told each other when using the product. Just think of how many people fell in love on a Vespa. Think of all the movies in which a Vespa appears. (Communication manager, Piaggio)

Alfa Romeo is a myth, but the pleasure of this myth - that is the pleasure of driving an Alfa-may have different reasons. Maybe it reminds you of grandfather's car with the Alfa Romeo logo with the serpent ... so you remain attached to that initial image of a brand you loved, you saw around the house, or in a movie, or a memory, however emotional, of years before. (President of the Alfa Romeo Club, Alfa Romeo)

Intuitive recontextualization

This is a [leaflet] from 1956 ... those who work in the fashion world, by looking at these things ... they manage to make a leap, by imagining how they can reuse it on their products ... I do it by default. (Head of licensing and business development, Piaggio)

Some years ago, we produced this lamp. And I took them (and others that I saw in the warehouse), because they are useless for our technical department, but I think we can organize an exhibition using them. We organized an exhibition in which we put those lamps with Chinese soldiers ... we had a room full of these men, colorful men, just to create a scenography in temporary exhibition. (Museum curator, Alessi)

Concept cars must project us into the future to inspire an expansion of the range, but at the same time have to be recognizable as Alfa Romeos. Which means that certain elements of style or treatments must remind the viewer about the tradition of the brand. So, it happens that we visit the museum to brainstorm in front of testimonies of this tradition. The same goes for colors and materials. The idea for this leather surface was already present on the Giulia 13000 GTA. By picking up this idea and reinterpreting it with new technologies and materials, we develop a new sport seat. (Chief designer, Alfa Romeo)

Historical artifacts as symbolic resources

[The museum] is a continuous source of stimuli. There is always someone asking to study [an object from the collection] to use them on calendars, sweatshirts, or even in a movie.... [Thus] the museum supports the enhancement of the brand in many ways, ranging from the supply of material for the publication of books and calendars, to all the archival material [required] to continuously renew the brand. (Communication manager, Piaggio)

[We try to give objects] a form that keeps into account and reminds [everyone] of the historical value or historical assets of the organization. (Chief designer, Ducati)

At that time, there was a whole research being conducted into colors ... Some of those colors have inspired the re-editions [of objects from the 1960s, 1970s, and 1980s] for the MoMA Shop in New York. For example, we applied yellow, red, or white-I remember these very 1980s' nuances of red and yellow-to the wire baskets ... They took some pieces from the Programma 7, and they also liked very much these colorful interpretations of the wire baskets. (Museum curator, Alessi)
While they did not focus exclusively on one to the exclusion of the others-distinctiveness, as we have explained, was a pervasive concern-they tended to emphasize one particular definitional standard in using material memory to construct identity understandings. This different prioritization of the definitional standards led members to interpret differently how the past was relevant to organizational 
identity and adopt different temporal perspectives in using material memory to support their tasks. Thus, they described identity as based on a consistent trajectory, timeless essence, or unique heritage, as discussed below.

Identity stewardship: Prioritization of enduringness (identity as a consistent trajectory). Some informants understood organizational identity as derived from an enduring "legacy" or "tradition" that they felt compelled to preserve in the present and future (see examples in Table 4). The chief designer at Piaggio, for instance, told us how important it was that his actions did not "interrupt the thread between the past and the future." Designers, he explained, must "manage to identify the signs that define and characterize a brand ... If you have no knowledge of the history of the brand for which you are working, you cannot even think of interpreting it in a contemporary way."

Organizational history, therefore, informed these informants' identity understandings by enabling them to reconstruct trajectories of past actions, and to identify within them the consistent choices that pointed to the enduring aspects of identity. Such aspects included technological features (e.g., the desmodromic gear and trellis frame of Ducati motorcycles, the "drivability" of Alfa Romeo cars, or the steel frame of Vespa scooters), as well as stylistic traits (e.g., the "trilobe" front of Alfas, or the omega shape of Vespas). As Ducati's CEO explained:

Our future depends on our past and it is made in continuity with important traits, which our museum somehow represents ... The 1098 is a bike we have just launched ... it has in itself a set of traits that are not in the mind of a genius, but in the history of Ducati. Traits that are consolidated ... the will to maintain a certain canon, which means a downward angle, the eyes of the beast, not vertical, but horizontal ... all traits that are typical of the Ducati tradition; that is, the trellis frame, the desmodromic gear, the twocylinder engine.

As is evident in the above examples, members in this mode aspired to be "faithful to the past and the tradition" (museum curator, Ducati). "We alfisti," said the head of Automobilismo Storico, a unit that included the museum, the archives, and the historical racing team, "believe in what has been handed over to us, and that we honor until the end." Historical artifacts enabled these informants to "defend history" (marketing manager, Alfa Romeo) and to claim continuity in organizational actions with internal and external audiences.
Identity evangelizing: Prioritization of centrality (identity as timeless essence). Informants adopting an identity evangelizing mode focused on what they described as the "soul" of the organization or its fundamental "values" (see Table 5 for examples). As the museum architect at Ducati explained:

[At the museum] the motorcycle [is] treated not so much as an object to be displayed, but as the concrete expression of an ideal of speed, of a legend, and a cult, with constant reference to positive values of competition ... [The museum] represents and idealizes, in visual terms, the very same speed that is the goal of the work being carried out just a few meters away.

Similarly, a senior manager at Alfa Romeo described how the museum had been redesigned to express these values more explicitly:

We decided not to arrange [cars] in a purely chronological order, but to try to present them according to specific themes that would be easy to memorize and offered an interpretation of the peculiarity and typicality of Alfa Romeo. The two strong values that characterize Alfa, in our view, are bellezza [which translates to "beauty," but is deliberately left untranslated even in texts in English] and speed.

Informants in this mode turned to the organization's history not to understand and compare detailed sequences of events, but to grasp what they viewed as the essential qualities of their organizations. For example, Alessi's museum curator told us that the museum conveyed the "Alessiness" of Alessi. Other informants described collections as representations of the "essence" or a "distillate" of the organization. Intertemporal consistency and seamless continuity seemed less relevant to these informants, as they saw the central distinguishing features of their organizations in terms of a few abstract and ideal qualities and values.

Heritage mining: Focus on distinctiveness (identity as unique heritage). Compared to the other two engagement modes, informants associated with heritage mining were less concerned with how historical artifacts represented either the enduringness or the centrality of organizational attributes. Instead, they used historical artifacts-ranging from iconic products to more mundane technical drawings and instruction manuals - with a great deal of flexibility. They described the museum collections and archives as a "gold mine," a "casket," or a "treasure trove" to which they periodically turned for inspiration for new products, merchandising, or advertising campaigns (see Table 6). 
These informants preferred the term "heritage" to identity. They used this term to refer to a unique and valuable body of objects, memories, and meanings, inherited from the past and available in the present, which they saw as an asset to be "leveraged" (CEO, Ducati) to distinguish the organization from competitors. As the design manager in charge of clothing collections at Piaggio explained:

Our competitors do not have a history they can spend and that they can use as we do. This allows us to differentiate ourselves from our competitors. Only brands that have a story to tell can develop [lifestyle collections] ... so, for a company like ours that has a very long, fascinating, and well-known history, this is a strong element of differentiation.

\section{Primary Referent Audience in the Mnemonic Community}

Organizational members in different roles prioritized definitional standards differently because of the differences in the audiences that they sought to engage- that is, their "primary referent audiences." Informants saw their audiences as varying in levels of knowledge of and attachment to the organization's history. These differences can be understood as varying degrees of participation in a mnemonic community centered on the organization.

Mnemonic communities consist of individuals that share a common memory of a collective past, which may not necessarily coincide with their own personal recollections, but is important for their collective identity (Zerubavel, 1996). This collective memory is sustained by collective practices of remembrance (Misztal, 2003), including narratives of the past, commemorative events (Schwartz, 2000), and the construction and visitation of memory sites (Nora, 1989).

In the four cases we studied, a diverse set of actors, both inside and outside the organizations, had contributed to preserve and transmit memory of the organizational past. Inside the organizations, even before the museums were founded, employees spontaneously collected historical artifacts, and occasionally celebrated past accomplishments. Outside, loosely organized communities of collectors, connoisseurs, and fans, as well as arts and cultural institutions, contributed in different ways, such as through gatherings, reenactments, and exhibitions, toward perpetuating the memory of the organizational past. Consumer enthusiasts, who referred to themselves as "alfisti," "ducatisti," or "vespisti," regularly visited the museums, and occasionally used them to gather together or to celebrate anniversaries of historical models. Informants used religious metaphors, such as "temple," "cathedral," or "Mecca" to describe what visits to the museum represented for these individuals (and even for themselves).

At Alfa Romeo, some informants argued that the community of fans and collectors organized in hundreds of clubs around the world had done more for "keeping the memory alive" in recent years than senior management had. As the head of Automobilismo Storico explained:

Alfa employees are not necessarily alfisti. I arrived at Alfa in 1977, but I had been an Alfista since I was twelve. Here, I found that there were people that did not know the history of Alfa well, and there were other that were also alfisti.

Informants' accounts, then, suggest that the mnemonic communities centered on the organizations involved audiences who exhibited varying degrees of involvement. This observation is consistent with research in social memory studies suggesting that whereas some people adopt the collective memory as their own and become involved in its maintenance, others maintain a degree of distance between collective representations and personal beliefs (see Zerubavel, 1996, for further discussion). Varying levels of involvement, in our context, implied different demands and expectations, which members sought to respond to by bringing the past into the present in different ways, and through different modes of engagement.

\section{Identity Stewardship: Maintaining Legitimacy with Core Members}

Identity stewardship was common among designers and engineers, who stressed how important it was for them to meet the expectations of specific audiences, such as fans, collectors, enthusiasts, but also critics and other designers-whom they described as having both high levels of knowledge about the organizational history and strong views about "appropriate" or "inappropriate" stylistic or technological product features (see Table 4). As one informant explained:

These are people who can look at the car and tell you: "This is an Alfa ... This is not an Alfa." They can be really harsh: although they have strong, positive feelings for the brand, they can also be quite severe 
when criticizing drifts or poor interpretations of what, according to them, Alfa Romeo is.

We refer to these actors as "core" members of their respective mnemonic communities, as they actively contributed to the maintenance of collective memory by participating in discussion forums, historical reenactments and other collective events, or writing blogs and articles about the organization and its products. "There are people who have Ducati tattooed on their neck," the vice president (VP) of sales at Ducati told us. "There are people who go on a pilgrimage of 3,000 $\mathrm{km}$ to come to the World Ducati Week." These people were also quite vocal about the importance of respecting its "legacy" and "tradition." At Piaggio, informants referred to a segment of their customers as "fundamentalists" because they would not accept technological improvements, such as an automatic gear, on the old PX model, designed in the early 1970s, which still represented about $15 \%$ of the total sales of Vespas. Ducati's CEO amusedly recalled how, when they considered eliminating the desmodromic valve in a lower-tier model to save 50 euros per vehicle with no performance loss, fans strongly rejected the idea, compelling the company to do the same.

Identity evangelizing: Identification of new members of the community. Identity evangelizing was more common among brand managers, HR managers, and other positions in which the role required conveying an attractive representation of the organization to audiences, such as new recruits, salespeople, dealers, and customers, who typically knew little about the organization's history. As the curator of the Alessi Museum told us:

Most of the visits we organize are for people that have to sell Alessi in the world, and a visit to the museum has always been part of the induction [of new recruits] because it gives an idea of our identity ... At the museum, there is everything we have been until now, so, by narrating some projects that for us are iconic of the Alessi identity, we transfer to these people what Alessi is.

Exposure to historical artifacts thus provided means for the mnemonic socialization of new or potential members. As the CEO of Ducati explained:

There's a large share of our fans who are connected with our history of racing, and [through the museum] I wanted to recover that... In order for new generations of ducatisti to understand and to experience the historic legacy of this company, it was necessary to give it tangible form.
Whereas identity stewards' primary concern was legitimizing action with core members, identity evangelists focused on expanding the community's boundaries, and invigorating identification among current members. For example, the communications manager at the Alfa Romeo Museum told us:

The museum now looks at new alfisti. It wants to contribute to broaden the audience of the brand lovers and, hopefully, future clients. The museum has a solid pool of fans who value this place as a temple and come at least once in their life.... That used to be our core audience, but now we [also] want to cater to those who maybe do not know the brand well. They have heard of Alfa Romeo, but do not know its history.

The international sales manager concurred, observing, "Every time we use the museum, the emotional level, the involvement, the passion of people coming out of it is considerably higher than what we could get with any publication on the history of Alfa Romeo." Indeed, informants consistently highlighted feelings of "belongingness," "involvement," "pride," or "passion" that visits to the museum promoted (see Table 5 for details).

Heritage mining: Significance for peripheral members of the community. Finally, heritage mining was primarily adopted by informants addressing a broader audience that could be described as "peripheral" to the mnemonic community. These individuals were neither involved in mnemonic practices nor highly identified with the organization, yet, informants pointed out, the organization was meaningful to them because of personal experiences (in Italian, "vissuto personale") and exposure to its products and communications. As the brand manager of Piaggio noted, for instance, products like Vespa and Ape-a popular three-wheeled commercial vehicle-were not only well known, but also personally meaningful to many (see Table 6).

Informants in this mode considered the possibility that their efforts might increase identification among consumers, but their primary concern was to increase the appeal of new products, communication events, or other initiatives for broad audiences. They saw symbolic references to a unique past as a means to induce these audiences to purchase new products, often outside the core product offerings.

\section{Cross-Temporal Sensemaking and Interpretive Uses of Historical Artifacts}

The prioritization of different definitional standards, based on the construed concerns and expectations 
of primary referent audiences, influenced the interpretive processes that members adopted when using material memory to develop task-relevant identity understandings. We conceptualize the processes through which members searched the past for cues to address present concerns and inform future action in terms of "interpretative uses of artifacts" and "crosstemporal sensemaking." This conceptualization is consistent with prior research theorizing the construction of identity understandings as primarily a retrospective sensemaking process (e.g., Gioia, Price, Hamilton, \& Thomas, 2010; Ravasi \& Schultz, 2006). Our observations, however, reveal different temporal patterns of identity construction within this process, induced by the prioritization of different standards.

Identity stewardship: Search for intertemporal patterns. The primary concern with enduring traits, displayed by members in a stewardship mode, was reflected in the use of historical artifacts as "identity markers"-signposts of trajectories in organizational action, manifested, for instance, in recurrent technological or stylistic features. As identity markers, historical artifacts aided the "search for intertemporal patterns" that provided the basis for understanding and claiming consistency in past actions. As the chief designer of Ducati explained:

The design of a new Ducati has to meet requirements of consistency in form and philosophy. This consistency is manifested in a number of traits that characterize every new Ducati ... The motorcycles preserved in the museum allow designers to experience directly the visual, tactical, experiential, and technical elements through which these traits have manifested over time, and to ensure the consistency and recognizability of each new model.

To infer patterns of action from historical artifacts in museum collections, members systematically compared artifacts from different periods, searching for similarities and connections from which they could infer principles that had guided past choices (see Table 4 for examples). An engineer at Piaggio, for instance, recalled that, when entrusted with the task of designing a new Vespa for the 60th anniversary of the product, he turned to the museum before even drawing the first few lines:

I came to see how prototypes were made, what the philosophy of D'Ascanio was ... I tried to understand how much care was taken in the course of the last 60 years to derive one model from the previous ... Between 1946 and 1977, Vespa has been modified every year with great patience ... At this stage, you humbly go to the museum and try to capture the differences in models from different years. That's why I tried to analyze motorcycles in detail, to understand the underlying philosophy and to try to readapt it. (Technical innovation manager, Piaggio)

Identity stewardship, then, reflected an interpretation of history as a temporally ordered sequence of actions and events, which could be tracked to construct a longitudinal trajectory of action. It reflected a temporal perspective on identity as derived from consistency of action over time, and implied continuity as a criterion for appropriate actions, in an effort to maintain legitimacy with core audiences. It therefore adopted an intertemporal form of sensemaking, prompting systematic comparisons of observations across time to derive meaning from the detection of consistent, sequential patterns, and prospectively projecting them into a trajectory of action to be followed in order to maintain legitimacy with core audiences.

Identity evangelizing: Holistic abstraction of essential features. Identity evangelizing involved a less analytical interpretative process. Informants in this mode were less concerned with tracking accurate sequences, genealogies, and timelines than those in an identity stewardship mode. Instead, they searched for coherence among noteworthy actions, events, and artifacts plucked from different points in time, unified by being seen and presented as exemplars of essential, often idealized, features of the organization.

When asked about how they produced these understandings, informants stressed the importance of exposing oneself to a multitude of artifacts that afforded an intuitive, holistic processing of the cues embodied in these artifacts, rather than engaging in systematic search and comparison (see Table 5). They described the exposure to museum collections as an "immersive" experience (curator, Alessi) or as "an experiential path, rather than something rational and structured" (HR trainer, Alessi). As the curator at Alessi elaborated:

Being in the middle of all this, amongst these 15,000 projects, is a wonderful full-immersion experience. One can understand in an immediate and intuitive way what Alessi is, its philosophy, and especially how in the last 30 years it managed to become a design company.

Other informants mentioned the particular stimulation they received from what they described as "atmosphere" (president of the Italian Alfa Romeo 
Registry) or "the air you breathe" at the museum (chief designer, Piaggio).

When asked to clarify and elaborate these statements, some informants had difficulties articulating their understanding of essential qualities of their organizations, often presenting it as a meaningful but undifferentiated experience (e.g., the "Alessiness"). Others mentioned the more abstract qualities that historical abstracts symbolized, individually or taken together (see Table 5). The chief designer at Piaggio, for instance, stated that the collection, as a whole, "testified the value of innovation that characterized the company." The senior product development manager at Alessi remarked that the multiple prototypes on display "bore witness of the depth of design behind a silverware tray."

These quotes illustrate how informants viewed and valued historical artifacts as "organizational relics" that symbolized the "passion," "mastery," or "genius" (see Table 5) of those who had made them and used them. According to informants, the motorcycles displayed at the Ducati museum were not simply "bikes"- they were Mike Hailwood's bike or Marco Lucchinelli's bike. Old Alfa Romeos brought "together reality and imagination" (Alfa Romeo, museum curator) by being associated with legendary drivers who had won memorable victories. As the sales manager at Alfa observed:

In the museum, you can find samples of products that really wrote glorious pages [in the history of motors]. Here, you can physically see them, with certain accessories, certain features, certain tires, which brings you to really connect directly to the accomplishments that were carried out with them.

Compared to identity stewardship, then, identity evangelizing was associated with experiencing history as a source of distinction that was less dependent on consistency, and more on the extraordinary accomplishments that, taken together, were interpreted as reflecting distinguishing qualities and values. The underlying sensemaking process constructed meaning by connecting cues abstracted from the actual temporal contexts and timelines to build a representation of the organization that was claimed as essential, in that it transcended time in order to ensure coherent expression of these essential qualities and values.

Heritage mining: Intuitive recontextualization. In the absence of pressing concerns with claiming either enduringness or centrality, heritage mining resulted in creative "recontextualization" (see also Hatch \& Schultz, 2017)—that is, in the reuse of symbolic or aesthetic elements of historical artifacts into new objects, often serving an entirely different function, in order to increase the significance and appeal of these objects for a target audience. The head of Licensing and Business Development at Piaggio explained:

The basis of our work is to carefully study the archives, with an eye on what can be developed, how to make contemporary what would otherwise be undervalued if used as they are.... You need to study well all these materials to have commercial and creative resources to meet potential licensees to discuss how your brand can be interesting for them ... to find new business opportunities.

Informants viewed recontextualization as a creative process that happened automatically, or, as the previously mentioned informant told us, "by default." Other informants referred to personal "sensitivity" (design manager, lifestyle and fashion, Piaggio), or something "difficult for us to explain ... it is something we feel."

Well-known historical artifacts that had acquired particular significance among fans or the general public, such as Alfa Romeo's four-leaf clover logo for sports cars, had become obvious candidates for reuse. However, informants described the search process as more open ended and dependent on them exposing themselves to a multitude of historical artifacts, searching for "inspiration" but without precise search targets. The archivist of the Piaggio Museum marveled at the capacity of some designers to intuitively grasp the symbolic potential of historical artifacts.

Some are struck by the history of this product and manage to get to something contemporary by reelaborating the historical ... The object in front of them ... which may not look much to you in the beginning ... becomes alive. We have seen it in a beautiful merchandising line.

Even relatively obscure and mundane objects, such as a technical manual, archival photographs, or technical drawings, could possibly be picked up for reuse, if informants envisioned a valuable opportunity to do so. For instance, the head of licensing and business development at Piaggio showed us a preview of the use of images and slogans from brochures from the 1950s and 1960s to inspire licensing initiatives about the popular three-wheel commercial vehicle Ape, produced by Piaggio since 1948. She explained that:

The way we used these visuals, these color blocks, is quite current, contemporary. It could be also reinterpreted ... It could inspire ideas for packaging. People 
who are used to doing this can envision several uses. Here, we also added the very popular slogan "It helps you earn money."

The process was largely prospective, in the sense that historical artifacts were not used to understandor represent-the present in terms of the past (as in the other two modes), but to envision new trajectories for the present and the future (how what the organization was once can be used today). Like the Carlsberg managers and consultants described by Hatch and Schultz (2017), informants adopting this mode tended to value historical artifacts more for their potential current reuses-that is, their contemporary relevance-than for their particular object history or position within an organizational genealogy.

\section{Impact on Choice of Appropriate Action}

The sensemaking processes described in the previous section reflected three different temporal perspectives (and the definitional standards they prioritized) that influenced the artifacts that members paid attention to, and how they interpreted the relevance of these artifacts for their task. These perspectives also provided them with different criteria for evaluating the appropriateness of action.

Grounding identity understandings in past trajectories (reflecting the prioritization of enduringness), identity stewardship led members to pursue continuity, and to channel innovation within a consistent sequence of technological and stylistic choice. Grounding identity understandings in essential qualities and values (reflecting the prioritization of centrality), instead, led members to focus on their coherent expression and reinforcement through the valorization of past accomplishments as symbols of these essential features. Finally, grounding identity understandings in the agglomeration of objects, symbols, and stories they called "heritage," heritage mining led members to focus on artifacts that uniquely symbolized aspects of the past that people would find meaningful today. Contemporary relevance, then, rather than continuity with tradition or coherent expression of essential values, was the criterion that guided their action.

Identity stewardship: Innovation within tradition. Identity stewardship motivated members to ensure continuity with features that they had identified as consistently distinguishing the organization. This led to a particular approach to innovation, which we term "innovation within tradition." In our cases, these efforts were most visible in features that characterized products at Ducati, Alfa Romeo, and Piaggio- the three cases that were subjected to more intense pressures from external audiences (see Table 7 for examples). At Piaggio, for instance, a team of designers and engineers relied on the careful analysis of museum pieces to define a number of features, such as the shape of the front plate, the rear "hips," and the steel frame as distinguishing the Vespa-in all of its various incarnations-from other scooters. Similarly, the chief designer of Ducati explained, "When we have to design a new bike, we think of our past, our stylistic elements, the proportions that characterize our bikes in particular, and distinguish them from others."

Informants across cases proudly shared stories about new models being identified as a Vespa, an Alfa, or a Ducati in the absence of visible logos, even by casual observers during trial runs. They saw these instances as evidence that they had been able to create continuity in product design that audiences both recognized and valued. They also shared examples when such efforts were not successful, as their analysis occasionally missed elements that their audiences considered important. The chief designer at Ducati, during a guided tour, for instance, recalled that, when designing the 999 model, they had underestimated the importance of the rider posture:

It took Tamburini six years to design the 916 . . Y You see these other bikes here? They are more recent models, but they still maintained the same downward front line, aggressive posture ... Look at this one. The 999. It is different: see how the posture of the driver is more erect? We made a mistake ... If you look at these other models, you see how we made an effort to recover the traditional lines.

Identity evangelizing: Valorizing the past through commemoration. Identity evangelizing manifested in a broad range of commemorative practices-ranging from historical reenactments and celebrations to mandatory visits to the museum for all new recruits (see Table 8 for other examples)—through which the past was valorized as a symbol of essential qualities and values in the present, such speed and beauty for Alfa Romeo, or transgression, experimentation, and respect for the ideas of designers for Alessi.

Sociologists of memory refer to mnemonic practices as "commemorative" when their scale, scope, or their levels of organizational investment and audience engagement infuse the object of commemoration with "extraordinary significance" and a "qualitatively distinct place in our conception of the past" (Schwartz, 1982: 377). In our context, these practices 
TABLE 7

Identity Stewardship: Innovation within Tradition

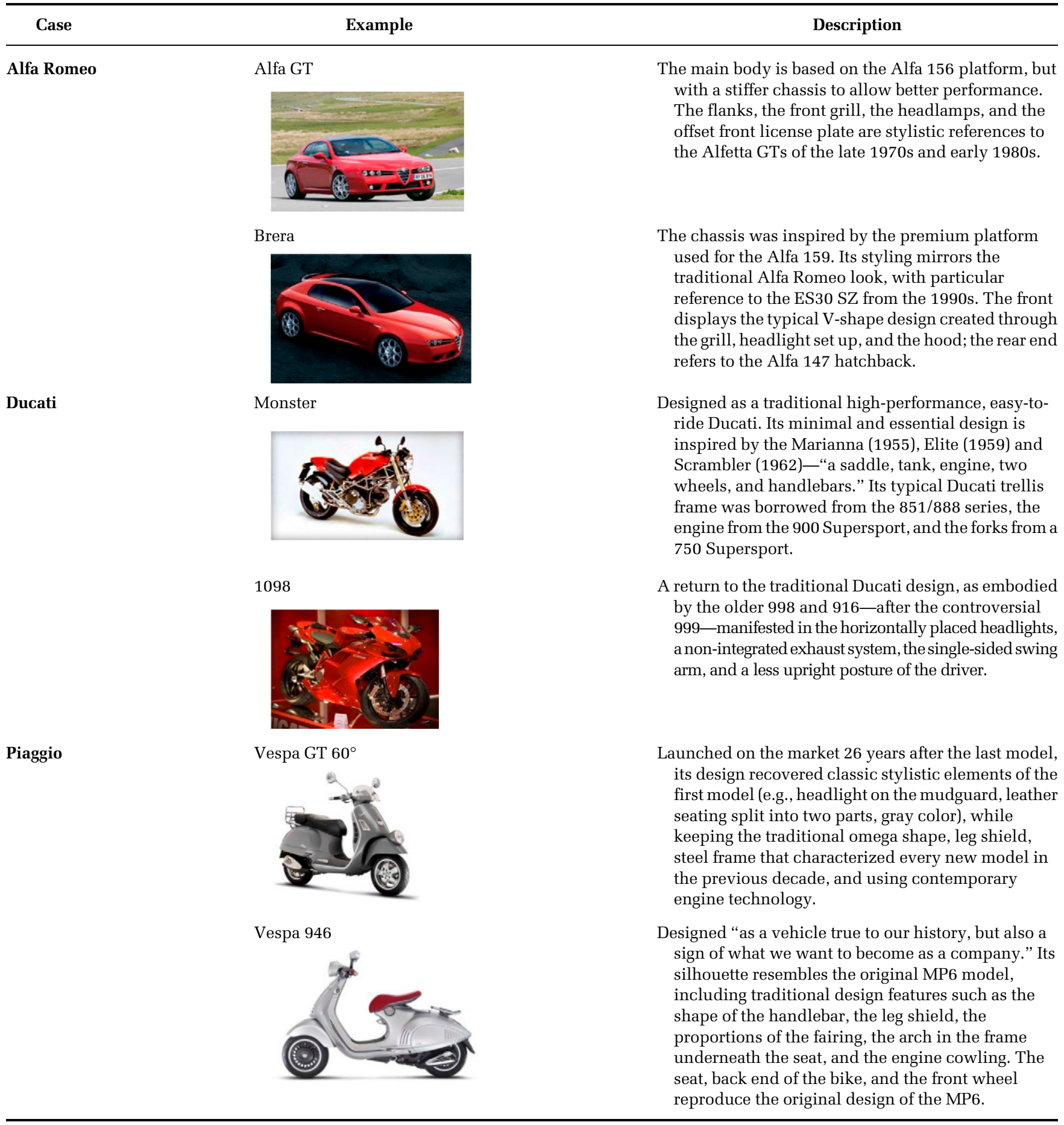

involved, for instance, the use of historical narratives about past accomplishments, path-breaking ideas, or legendary heroes in various forms of communication, including exhibitions, product launch events, advertising campaigns, anniversary gatherings, and other events (see Table 8 for examples). These events were intended not only to enthuse new potential members of the mnemonic community, but also to inspire, encourage, and support a wide range of mnemonic practices through which a 
TABLE 8

Identity Evangelizing: Valorizing the Past through Commemoration

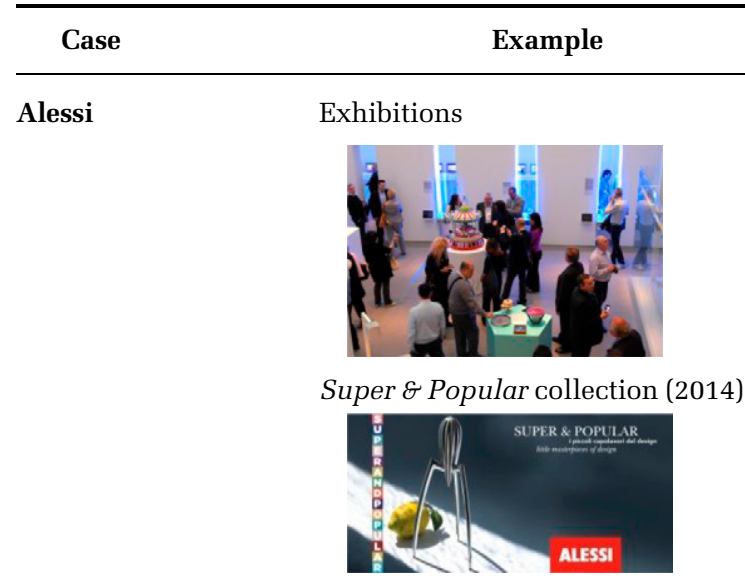

Alfa Romeo

\section{Ducati}

Piaggio
Museum concept

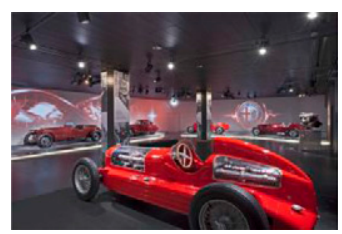

Product launches

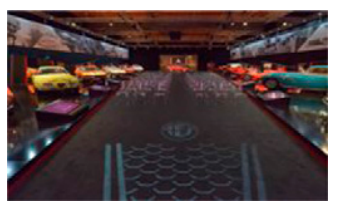

Museum concept

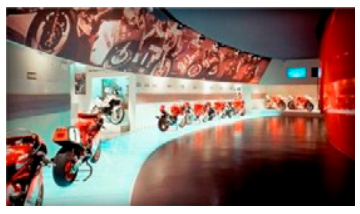

World Ducati Week

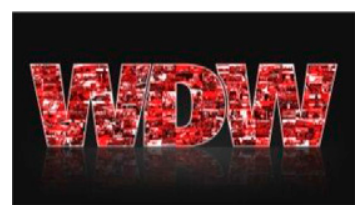

FuturPiaggio

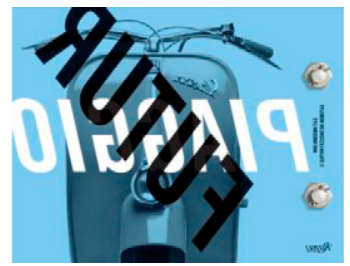

Vespa brand book
Description

Beginning with The New Domestic Landscape from the Triennale Museum, in Milan, and The Alessi Workshop at the Centre Pompidou, Paris, over the years, Alessi has regularly promoted or supported exhibitions that draw on prototypes and other historical artifacts, as a way to "educate the public about Alessi's unique approach to design."

In 2014, Alessi gathered its most “iconic” pieces, considered landmarks in the contemporary design, in a new collection aimed at "representing the company's approach to design." The name mirrored a term coined by CEO Alberto Alessi in the 1990s to convey the essence of this approach. The new packaging and the communication campaign drew from the company's archives and library.

In 2015, the museum was refurbished with a deliberate intent to support the relaunch of the brand. The new display highlighted the core values of speed (a reference to the glorious racing history, represented by historical racing cars, old videos, trophies, etc.) and beauty (expressed through a selection of historical and concept cars), alongside a timeline of noteworthy historical events and figures.

To launch the new Giulia on the Spanish market, Alfa Romeo organized an exhibition, titled Museum of Emotions, that showed historical models from the museum alongside the new car. Managers intended "to provide an overview of the company's 106 years of history, and to promote the values underpinning the Alfa Romeo DNA"- that is, beauty and speed.

The CEO intended the museum itself to be a "cathedral" where Ducati fans could express their "faith." The museum was designed to highlight values of speed and performance, associated with Ducati, by celebrating racing triumphs through historical vehicles and other memorabilia. Accordingly, it displayed only sports motorcycles. The recent stylish refurbishment of the museum reflects an enriched understanding of Ducati as being about "style, sophistication, and performance."

On the occasion of its foundation, the museum hosted the first World Ducati Week. The event, open to all Ducati fans, combines parades of current and historical vehicles with trials of racing skills during track sessions, open visits to the museum and the factory, and other events intended to reinforce a sense of collective identity around the past and present of the company and its products.

To celebrate its 130th anniversary, the Piaggio Group published a book entitled FuturPiaggio. According to CEO Roberto Colaninno, the book was intended to communicate the "love for innovation" and "capacity to imagine a future invisible to others" that characterizes Piaggio, and to convey an essential view of Piaggio as "delivering innovative mobility solution" through "milestones in the history of Piaggio," the "most iconic products," and the "story of men and brands ... at the cutting edge of innovation."

In 2005, the new brand book, defining the positioning of the Vespa brand, used historical references to highlight its being "a cult object," "a timeless archetype of contemporariness," and a "historical symbol of social freedom and freedom of movement." 
desired representation of the organization and its past were constructed or perpetuated.

The design of the museums themselves often reflected a conscious attempt to express core "values" through the organization and selection of the collection on display. For example, while the initial design of the Ducati Museum, as the original curator told us, aimed at highlighting "historical chronology" and "technological progress," its recent restyling emphasized an aspect-style-that the current management considered central to Ducati, even if it could not be claimed to have characterized consistently the organization as much as technological innovation had. The new website described the design of Ducati bikes as "the essence of Italian style." The renovated display gave preeminence to iconic bikes that symbolized "style, performance, and the search for perfection," rather that the "technological families" around which the previous one was organized.

In some cases, the valorization of the past led to the articulation of synthetic expressions of essential qualities or values in the form of brand guidelines or new corporate slogans. Initially intended to ensure coherence across communication activities, they occasionally had more wide-ranging and long-lasting effects, as the holistic understandings that they produced inspired and energized coordinated strategic efforts. Reflections on the radically innovative products it had introduced in a distant past, for instance, led senior managers to define Piaggio's distinctive character as offering "innovative" and "intelligent mobility." This conceptualization of the organizational identity led to radical redesigns of light vehicles in the 2000s, such as the first three-wheeled scooter MP3 (released in 2006), which created a whole new segment in the scooter market (see Table 8), and the personal cargo-carrier robot GITA (see https:// piaggiofastforward.com/gita).

Heritage mining: Using historical symbolism to add value to new offerings. In the cases we observed, the tangible outcomes of heritage mining were new products infused with symbolic references to an organizational past that was still remembered and experienced as meaningful by referent audiences. Examples largely fell in the domain of brand extensions to new product categories, such as clothing and accessories. Old logos that had adorned the body of Alfa Romeo racing cars and Ducati motorcycles were transferred to sports jackets or caps. Alessi reproduced its iconic kitchenware as miniatures that lost their original function but fit collectors' needs (see Table 9 for details). Images from old Vespa advertisements decorated beachwear and baby clothes. The creative reuse of historical artifacts sometimes also led to new products that remained within the same category, but were released in limited editions (such as the Alfa Romeo 8c Competizione) or for targeted customers (such as the Ape Calessino; see Table 9).

According to informants, symbolically linking new products to historical ones, even if unrelated, created a sense of "authenticity"-an observation consistent with prior research (Hatch \& Schultz, 2017). As a designer from Piaggio observed:

\begin{abstract}
The new clothing line has been highly appreciated because guzzistis recognize themselves in these icons of Moto Guzzi, which we recovered thanks to our archival search. Without this link with the history of the brand, we would not have met our goals. Before, we had some items that did not sell well because they had been designed by external consultants and had graphics that alluded to the Guzzi world, but were not authentic.
\end{abstract}

The fact that target audiences had only fragmented memories and understandings of the organization and its products allowed some latitude in how historical artifacts were reused. Also, the use of historical symbolism in product categories that differ from the original ones avoided confronting the expectations of core audiences, who, for instance, might have opposed the use of the four-leaf clover-a traditional symbol of the racing team-on regular Alfa Romeo models, but appeared indifferent to its reuse in pendants or cufflinks, or even appreciated it.

The relatively flexible use of historical symbolism that characterized heritage mining, however, occasionally clashed with the concern for ordered sequences, clear patterns, and historical accuracy of identity stewardship. For example, a chief designer at one of the focal companies shared:

I am quite critical about some things I have seen, because they did not respect certain classical features ... There are implicit and unwritten rules. Trying to break away from conventions without a particular purpose ends up damaging the brand ... You see it on vehicles but also on merchandising. And I have to bite my tongue not to be more specific than that.

Informants that privileged identity stewardship, then, occasionally frowned upon products that, in their view, despite their market success, lacked the credibility of a continuous genealogy. A VP of engineering offered the following evaluation:

To be honest, I am quite convinced that picking up old stylistic elements and mimicking them on a new 
TABLE 9

Heritage Mining: Using Historical Symbolism to Add Significance to New Offerings

\begin{tabular}{llc}
\hline Case & Example & Description
\end{tabular}

Alessi

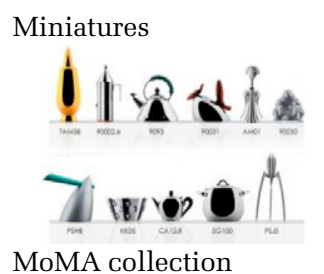

MoMA collection

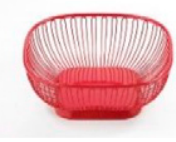

Alfa Romeo

Ducati

Piaggio
Merchandising

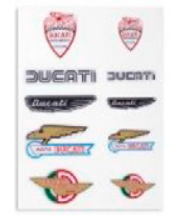

Sport Classics
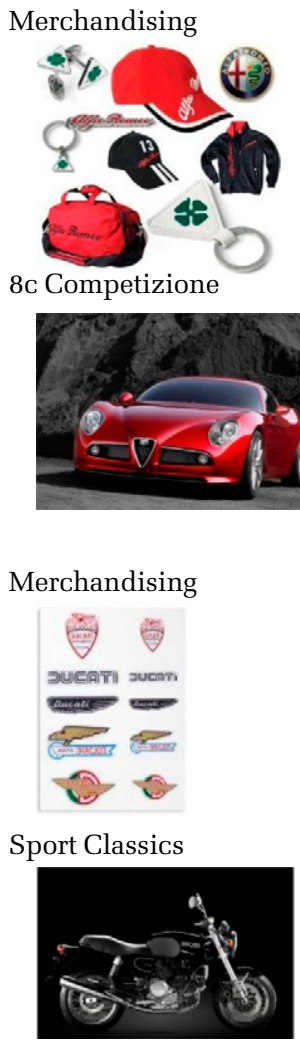

8c Competizione

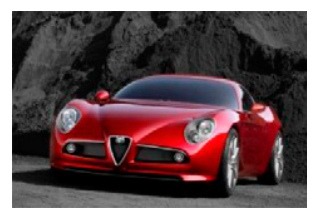

Ape Calessino

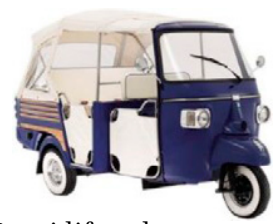

Guzzi lifestyle

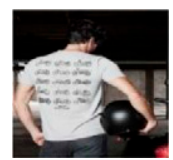

The Alessi catalog now includes a collection of miniature reeditions of 21 of their most popular products—objects considered landmarks of contemporary design. Unlike the originals, these objects serve no practical purpose, but are intended primarily at a collectors' market "to satisfy a deeply rooted desire for art and poetry."

A special edition collection, inspired by Alessi products of the 1970s and 1980s, to be sold exclusively at the gift shop of the Museum of Modern Arts (MoMA) in New York. These objects are modified re-editions (e.g., new colors) of original products designed by renowned designers Ettore Sottsass, Giulio Confalonieri, and Silvio Coppola, prototypes of which are included in the collection of the Alessi Museum.

Alfa Romeo sells different official merchandise objects developed internally and/or produced under license: clothing, accessories, stationery, etc. These products display the company logo and/or the traditional Alfa Romeo four-leaf clover, which historically distinguished racing cars. This collection includes a wine set, with tools shaped after engine parts and wine bottles displaying the Alfa Romeo trilobe on the label.

A limited-edition super sports wagon car. The name refers to the eight-cylinder engine that was used by Alfa Romeo racecars of the 1930s and 1940s, as well as to the 6C 2500 Competizione, which competed in the 1949 and 1950 Mille Miglia race. The lines and the front were styled after Alfas of the 1950s and 1960s with cowls over the headlights. The acoustic of the engine was carefully engineered to reproduce the typical sound of Alfa Romeo racecars.

Ducati sells various merchandise objects produced under license and developed with the support of the museum: keyrings, smartphone covers, stickers, and other artifacts that display the company logos or other historical images. These products, along with the licensed clothing line, contribute substantially to the revenues of a company that produces only tens of thousands of motorcycles per year.

The Ducati sports classic range included limited-edition retrostyled touring bikes, like the MH900e and Paul Smart LE, inspired by racing motorcycles associated with historical victories in the late 1960s and the early 1970s. They could be customized with accessories to accentuate the look of racing bikes of the time.

The Ape Calessino is a limited edition (only 999 have been produced), glamorous, and fashionable version of the original Ape Piaggio, a three-wheeled light commercial vehicle produced since 1948. The bodywork is close to the Ape of the 1950 s and 1960s and is designed to evoke memories of the era of dramatic economic growth in Italy known as "Miracolo Economico."

In 2016, Piaggio created the Moto Guzzi lifestyle collection of clothes, helmets, mugs, and stickers. The items in the collection have references to the history of the Moto Guzzi brand, which were retrieved by using the company archives as a source of information. 
product makes no sense. To put it simply, creating a fake or creating something modern that recovers basic ideas of the past does not help much.

The curator of the Ducati Museum, however, told us how his suggestion to design a merchandising gadget that displayed the timeline of historical logos had received only lukewarm support, while a similar object focused on the more widely known current logo of the racing team had been more successful. This observation suggests that, when addressing peripheral members of the mnemonic community, commercial success does not necessarily depend on historical consistency, as these audiences are less knowledgeable about the organizational past. Conversely, merchandise designers mentioned that, when their efforts targeted specifically core members of the community, they referenced the past much more precisely.

\section{DISCUSSION}

Our study examined how members in four organizations used material memory to construct situated, task-relevant understandings of what distinguished their organizations from competitors. We uncovered three distinct modes of engagement with history and identity, which reflected the prioritization of different identity definitional standards (enduringness, centrality, and/or distinctiveness), involved different cross-temporal sensemaking processes, and influenced organizational action in different ways (summarized in Table 3).

The identity stewardship mode led organization members to search for distinctiveness in the consistency of technological and aesthetic features valued by the mnemonic community. In this mode, historical artifacts provided cues to track past trajectories and continue them in future actions. Identity evangelizing, instead, led members to selectively focus on artifacts associated with noteworthy past accomplishments that were used to support present claims about essential qualities and core values of the organization. They did so to extend the boundaries of the mnemonic community and stimulate identification among internal and external audiences who shared the values symbolized by these accomplishments (Dukerich, Golden, \& Shortell, 2002) or could bask in their "reflected glory" (Cialdini, Borden, Thorne, Walker, Freeman, \& Sloan, 1976). Finally, in a heritage mining mode, members used the past flexibly, with less concern for either the enduringness or centrality of deemed identity attributes. Instead, they used artifacts that could be uniquely associated with the organization to enhance the significance and appeal of new offerings, by symbolically connecting them to personal memories and cultural imagery.

These observations do not seem to be unique to our setting. Past studies have described similar patterns-without, however, theorizing them as we do. For instance, Carlsberg's reuse of the longforgotten Semper Ardens motto to label a new craft premium beer and to inspire a new formulation of the corporate philosophy (Hatch \& Schultz, 2017) displays the flexible and creative recontextualization that characterizes heritage mining. In the early 1970s, Bang and Olufsen's attempt to codify "corporate identity components" to guide communication and design was based on a retrospective analysis of its historical production, to ensure the preservation of this tradition-identity stewardship-in the face of mounting pressures from Japanese competitors (Ravasi \& Schultz, 2006). In the 1990s, reflections on the organizational history supported the codification of what they referred to as the "essence," "spirit," or "fundamental values" of the organization, as attention shifted to evangelizing to ensure coherent support to brand positioning as the company strengthened the network of exclusive distributors (Ravasi \& Schultz, 2006). These observations reassured us about the transferability (Lincoln \& Guba, 1985) of our findings outside our setting.

By uncovering these different modes of engagement-and, importantly, the underlying interpretive processes (see Figure 1)—we were able to theorize core constructs and mechanisms that illuminate how members use history and memory to construct understandings of their organizations' identities, and explain the variant ways in which they do it. These observations have important implications for research on the construction of organizational identities, as well as on the role of material memory as a resource for organizational action.

\section{Implications for Research on Organizational Identity Construction}

Whereas past research has acknowledged the relevance of history as a basis of identity construction (Whetten, 2006) and the importance of examining the temporality of these processes (Schultz \& Hernes, 2013), there is still a lack of theorization about how members use the past as a "temporal resource" (Ybema, 2010). Our observations begin to shed light on the processes underlying the temporality of identity by theorizing how members use material 
memory for identity construction (see Figure 1) and articulating three distinct modes in which they do so (Table 3). These theoretical insights have important implications for research on organizational identity because they not only illuminate the influence of history and temporality on identity construction, but also encourage us to reconsider long-standing assumptions in organizational identity research.

Unpacking the temporality of organizational identity. "Temporality"- understood as the "ongoing relationship between past, present, and future" (Schultz \& Hernes, 2013)-has emerged as an important yet understudied aspect of organizational identity (Schultz, 2016; Schultz \& Hernes, 2019). This line of inquiry, however, is still in its infancy. While scholars tend to agree that members can use the past, present, and future as "temporal resources" (Ybema, 2010) to makes sense of "who we are" in the present (Ravasi \& Schultz, 2006) or "who we want to be" in the future (Ybema, 2010), we know less about what elements of the past they may pay attention to, how they connect them, and how such processes influence emerging identity understandings. As a result, the processes through which "organizational actors ... evoke the past and forge connections to the future" (Schultz \& Hernes, 2013: 2) remain largely undertheorized.

Our observations offer theoretical depth and specification to this line of inquiry, by revealing three different temporal perspectives on identity-that is, three different interpretations of how "who we have been" in the past is relevant to how we understand "who we are" in the present. These perspectives reflect the prioritization of different definitional standards, and shape the cross-temporal interpretive processes that members use to forge links between past, present, and future, with important implications for the courses of action they consider.

Prior research has given limited attention to the interpretive processes that enable members to trace specific links in time between the complex constellation of facts and events that constitutes the past in an effort to generate meaning and inform present-day decisions. This oversight stands in contrast with calls for closer attention to "the question of how interpretations of the past, present, and future are constructed and linked together in more or less radical ways" (Kaplan \& Orlikowski, 2013: 966). Our findings begin to fill this theoretical void by articulating the interpretive processes through which organization members establish "historical meaning" from the inchoate set of cues we call "the past" (Zerubavel, 2003: 13).
Both social memory studies (Zerubavel, 2003) and organizational research (Schultz \& Hernes, 2013) acknowledge that individuals make sense of the past by extracting and connecting cues from a chaotic and unstructured flow of events. From the perspective of organization members, Schultz and Hernes (2013: 4) have reminded us that "the past is constituted by a selection of 'memory cues,' [available to them] which do not always form coherent patterns." Individuals introduce order in this chaos by imposing "contrived" structures that transform an "essentially unstructured series of events into seemingly coherent historical narratives" (Zerubavel, 2003: 13).

While these ideas provide a point of departure for thinking about cross-temporal sensemaking, our findings offer a more elaborate theory of how different task demands shape how members "structure" the past differently. Organization members, our findings suggest, use historical artifacts in different ways as anchoring cues to structure a complex and chaotic stream of events; they also connect them into relatively ordered patterns or themes, from which they infer what the organization is (or has been). As they do so, the prioritization of different definitional standards channels these sensemaking processes in different patterns, as illustrated in Figure 2.

Identity stewardship, we find, involves searching for intertemporal patterns and consistent trajectories amid changes, and connects past and present by tracking sequences in prior executions of the same task (reflecting the prioritization of enduringness). It leads to envisioning future action as the projection of these trajectories in the future.

Identity evangelizing involves making atemporal connections and clustering different artifacts associated with organizational accomplishments to find coherence that attests to the presence of essential qualities. This sensemaking process tends to disregard the "objective time" stamps on artifacts (reflecting the prioritization of centrality) in order to leverage them in exemplification of "timeless" values to be expressed by future action.

Finally, heritage mining involves forging links between the past and present through the creative reuse of isolated historical artifacts, with a view of their contemporary relevance for a broad audience. The actions it inspires are less concerned with projecting the past into future trajectories that built on cumulative choices and experiences (e.g., consolidation of distinctive technological or aesthetic product features, or historically inspired brand-building efforts). They are aimed instead at making circumscribed use of elements of the past with a more 
FIGURE 2

Prioritization of Identity Definitional Standards and Patterns of Cross-Temporal Sensemaking
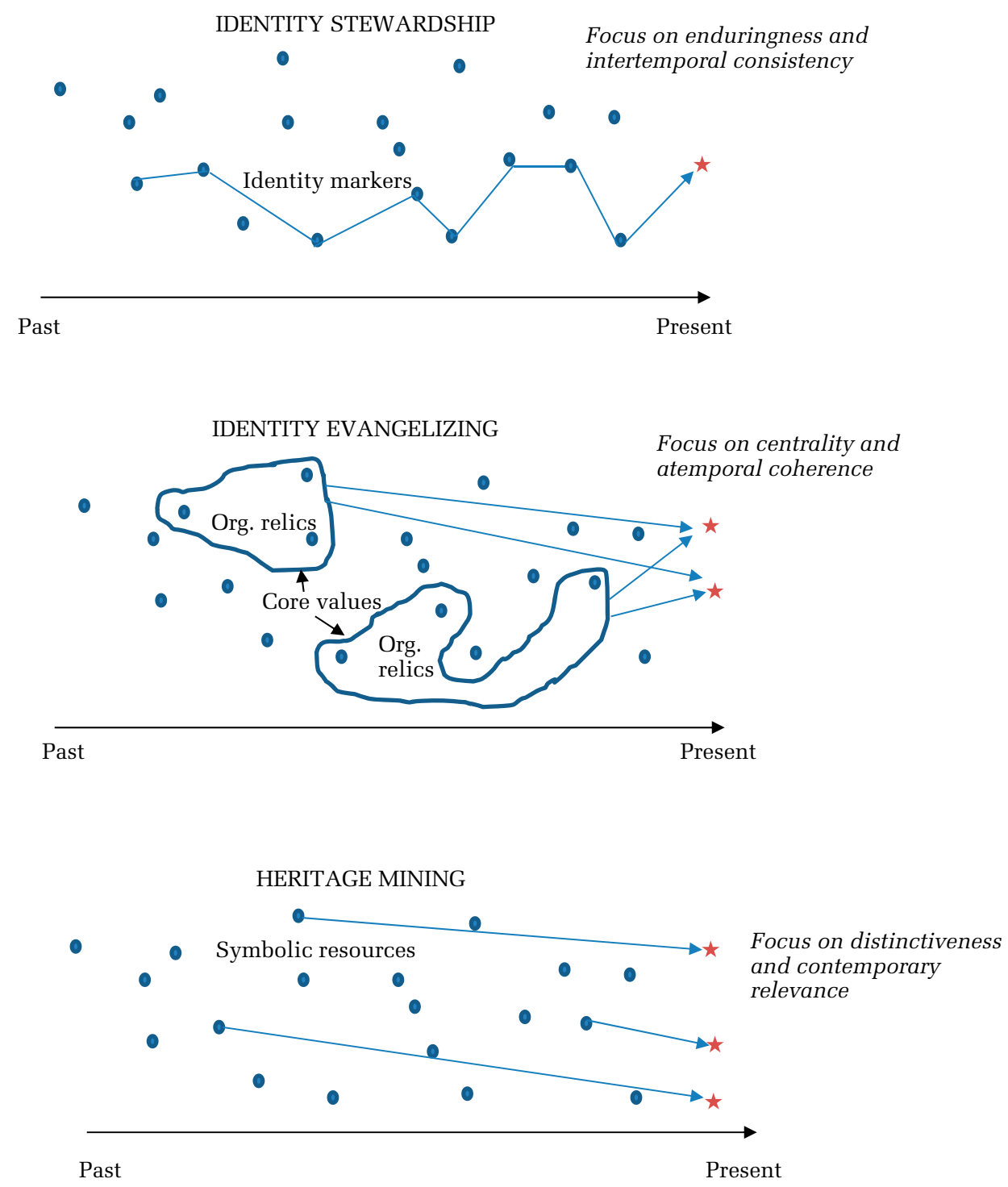

- Historical artifacts (memory cues)

$\star \quad$ Future-oriented action (in the present)

$\longrightarrow$ Cross-temporal linkages (past reused in the present)

short-term horizon (e.g., merchandising or limited editions).

These theoretical ideas about cross-temporal sensemaking extend beyond understanding identity construction. Scholars have recently argued that temporality is emerging as a central but underexplored area of research on strategic change (Kunisch, Bartunek, Mueller, \& Huy, 2017). Our study offers relevant insights for this area of study, as the effects on action we observe affected the renewal (or preservation) of organizational technologies, product lines, and brand attributes. Future research may use our ideas about cross-temporal sensemaking to examine how senior managers envision, present, and enact strategic and organizational change, and with what impact on audience responses inside and outside organizations. 
Organizational identity as situated cognition. Our findings also advance the idea that the identity understandings that inform members' actions may be, in part, situated and task-specific, and reflect the prioritization of different definitional standards. In doing so, they offer a novel perspective that invites us to expand how we think about organizational identity.

While recognizing the possibility that multiple identities may coexist in an organization, past research generally conceptualized organizational identity as a global property of an organization as a social actor (e.g., Whetten, 2006), or a relatively consensual, intersubjective social construction (e.g., Gioia et al., 2013) that becomes salient in times of change, conflict, or crisis (e.g., Corley \& Gioia, 2004; Dutton \& Dukerich, 1991). Research from the critical perspective (Brown, 2006; Humphreys \& Brown, 2002) moved away from this idea, drawing attention instead to the multitude of identity narratives that members weave to support or dispute decisions that affect personal agendas.

Our findings offer an alternative to these positions by portraying organizational identities as situated, task-related cognitions with substantial impact on decisions and actions. This view neither requires the assumption, which some view as a problematic, that organizations "have" identities (although it does not deny the possibility that relatively widely shared understandings about "who we are" may exist at any point in time) nor concedes the notion of organizational identities as being purely narrative based. By recognizing the grounding of members' understandings in "socio-material interaction" and the "temporary identity stabilization" that occurs as members act upon their situated understandings, our framework is compatible with a process perspective of organizational identity as an "ongoing accomplishment" (Sandberg, Loacker, \& Alvesson, 2015: 331-332). It shifts attention from the episodic, centralized, top-down events examined by past studies (e.g., Corley \& Gioia, 2004; Kjærgaard, Morsing, \& Ravasi, 2011; Ravasi \& Schultz, 2006) to the ongoing, dispersed construction of situation-specific understandings occurring in different parts of the organization, as new products are designed and brand campaigns developed.

This observation is important because it challenges the long-standing assumption that, when members ask the question "Who are we as an organization?," their answers reflect what they view as central, enduring, and distinctive of the organization (Albert \& Whetten, 1985; Whetten, 2006). Our findings show instead that, depending on the task and target audience, members may prioritize these differently, and that this differential emphasis influences significantly how they bring history and memory to bear on present action. By problematizing the widely accepted notions of centrality, enduringness, and distinctiveness as constitutive properties of identity, our study invites future research to explore this matter empirically.

More generally, our ideas offer a theoretical platform for future studies to examine how different situated processes interrelate, and how the situated, task-relevant understandings they produce inform the more global intersubjective understandings that have been the focus of the majority of past research. Future studies may examine, in particular, the relative compatibility of specific representations of the organizations produced through different forms of engagement, and its implications for coordinating actions across functions and target audiences.

When enacted "on the ground," the engagement modes we observed were at times a source of disagreement between members adopting different modes to perform similar tasks. For example, designers diverged in their views on a product, and different curators held diverse opinions about the appropriate curatorial choices. Informants, however, were reticent to elaborate or provide specific examples. Future work in the area may leverage research designs that enable researchers to observe directly work interactions centered on historical artifacts. An ethnographic study, for instance, may be well suited to surface latent tensions, as well as the micro strategies through which they are resolved on the ground.

Organizational identity as embodied cognition. Our findings also encourage us to reconsider the prevailing understanding of identity construction as an essentially linguistic accomplishment, based on claim-making (Glynn, 2000), labeling (Rindova, Dalpiaz, \& Ravasi, 2011), and/or narration (Brown, 2006). Past research has implicitly assumed that identity beliefs and understandings are reflected in the words members use to label their organization (e.g., a "world class orchestra" or a "design factory"). Our observations suggest instead that members' understanding of their organization may be partly intuitive, and it may affect organizational actions in important ways, without being either fully, or consciously articulated. Organizational identities therefore may rest on images and experiences that remain unsurfaced and unlabeled.

Our findings point to how these understandings may rest on specific processes associated with exposure to and engagement with historical artifacts. 
Museum scholars have advanced the idea that historical artifacts are used to symbolize collective national identities (Duncan, 1991; Bennett, 1995), and that they do so by performing a function that we could describe as "metonymical," as they stand for and represent a whole of which they are a part (Manning, 1979). In the case of identity evangelizing, this whole was frequently a glorious past-a "golden age"-populated by organizational heroes and outstanding feats, interpreted as an incarnation of the most essential qualities of the organization through a process of metonymical compression (Cornelissen, 2006), whereby the qualities of objects, people, or events were transferred to the whole, unique exemplars were generalized, and imaginative connections between different parts-some belonging to the past, some to the present-were stimulated. Whereas past research has recognized the centrality of metonymical processes in how we make and give a sense of organizations (Manning, 1979), it has focused exclusively on its narrative and linguistic manifestations (e.g., Cornelissen, 2006; Musson \& Tietze, 2004). Our observations suggest instead that metonymical processes may be also central to how materiality affects our understanding of organizations.

Our findings therefore provide support and theoretically elaborate an original insight that organizational identities may be, at least in part, "embodied" (Harquail \& Wilcox-King, 2010). They do so by suggesting that members' verbal characterizations of their organization may be partly grounded in less conscious experiences of how the organization manifests to them materially. This observation encourages us to rebalance the overwhelming attention of current research to cognitive and linguistic processes of identity construction, by examining more closely the influence of material stimuli and various emotional and imaginative responses to them.

\section{Implications for Research on Organizational History and Memory}

By focusing on specific uses of history, past studies have offered only partial theorizations of the phenomenon. Our findings, in contrast, advance our understanding of how history is used in organizations by suggesting that variations in uses of history-which past research foreshadowed, but left essentially unexplained-can be accounted for in terms of the cross-temporal interpretive processes that members use to connect past, present, and future, which are influenced in turn by the primary referent audience they address.
This observation stands in contrast with current research, which tends to present uses of history as centralized in the hands of senior managers or communication and marketing units for the purpose of supporting a desired image, market position, or strategic direction. In contrast, our study revealsand, importantly, theorizes-why organizational members in different roles may use history for different purposes and with different implications for organizational action. ${ }^{2}$ These findings offer a fresh perspective on how mnemonic processes inside and outside the organization constrain and enable organizational action in different domains.

Material memory as a resource for innovation. A core definition of organizational memory focuses on the informational content of archives and other repositories (Walsh \& Ungson, 1991). This view assumes that remembering occurs as long as historical records are available and the knowledge and information "stored" in them is available for "retrieval" (Hargadon \& Sutton, 1997; Moorman \& Miner, 1998). Our findings problematize this view, by suggesting that material memory-as a source of cues, rather than a "storage bin"-enables interpretive processes through which knowledge about the organizational past is periodically reconstructed to inspire novel action, reflecting a mix of concerns, both retrospective (e.g., preserving continuity) and prospective (e.g., inspiring innovation). The outcome of this process, importantly, remains relatively open because members retain flexibility in the cues they attend to and in how they connect and

\footnotetext{
${ }^{2}$ While our analysis highlighted the influence on members' engagement modes of the audiences that they interacted with because of their role, it is unlikely that role alone entirely explains this engagement. For example, we found indications that identity stewardship may characterize members that identify more strongly with the organization (Ashforth \& Mael, 1989), either because of their long tenure (Mael \& Ashforth, 1992) or because they are themselves fans of its products (Bagozzi, Bergami, Marzocchi, \& Morandin, 2012). It is also possible that the professional training of some informants (as historian or designer) might have led them to prioritize the historical and philological accuracy that characterizes identity stewardship. Because of the inductive nature of our inquiry, our interview protocol was not intended to "measure" informants' modes of engagement and/or their potential antecedents, because these explanatory constructs emerged only later in the analysis. This limitation, however, presents interesting opportunities for future research to explore how professional training, tenure, and other career-related factors may influence modes of engagement with history and identity.
} 
frame multiple cues to produce meaning with a view of the task at hand.

In the perspective we articulate, the very same artifacts may be used to produce different knowledge and understandings, depending on members' primary concerns and mode of engagement. We show, for instance, how members use historical artifacts as identity markers to manage tensions between the needs to innovate their offerings while preserving a tradition cherished by some of their audiences. Material memory affords them direct access to the features-and the patterns in their past consistency-that likely shape the expectations of their audiences. Singling out these specific technological or design features, as well as the more general principles that inspired them, enable organizational members to take actions more flexibly, by surmising the degrees of freedom they could allow themselves in specific feature redesigns or color choices.

We describe this approach to innovation as "innovation within tradition" to highlight the constrained yet generative nature of this approach to innovation. We note that our observations differ from what De Massis, Kotlar, Frattini, Messeni, \& Wright (2016) termed "innovation through tradition" to describe how an organization recovers traditional skills, techniques, designs, and materials as components of new offerings. In contrast, our focus is on how organization-specific past trajectories of action simultaneously inspire and direct the features that characterize new offerings. Taken together, however, both of these approaches point to the opportunity for future research to examine more closely how the organizational past not only constrains organizational innovation through path dependence (Sydow, Schreyöggm, \& Koch, 2009) but also enables organization-specific trajectories of innovation, growth, and strategic renewal.

Mnemonic communities, uses of history, and organizational action. By articulating how members' engagement with history and memory depends on how they construe the expectations of different audiences in a mnemonic community centered on the organization, our study brings the concept of a mnemonic community to the forefront of the analysis of uses of history in organizations, and it begins to shed light on how these communities influence both the uses of history and organizational action.

Despite Gioia and colleagues' warning that "revisionist history must be plausible to the intended audience" (Gioia et al., 2002: 631), research on uses of history seems to assume that organizations enjoy a wide latitude in their capacity to amend historical records (Anteby \& Molnar, 2012), revisit their biographies (Rowlinson \& Hassard, 1993), craft new narratives (Suddaby et al., 2010), or reuse historical artifacts (Hatch \& Schultz, 2017). Collectively, these studies advance a view of history as a flexible rhetorical resource that can be used with limited external scrutiny or constraint.

In contrast, our study shows that uses of history may be embedded in a web of mnemonic practices carried out partly outside the organization. These practices, our findings suggest, will influence how history is used, either because of the pressures that members feel from the mnemonic community to act in continuity with the past, or because of the opportunities that they envision to connect with collective memories to reinforce this community and extend its boundaries.

We view the felt pressure to act in continuity with the organizational history as a historical imperative that parallels the categorical imperative that arises from categorization and classification schemes that generate pressures on organizations to conform to the prescriptions of the categories they are members of (Hsu \& Hannan, 2005; Zuckerman, 1999). We view both types of imperatives as arising from audiences' expectations, but with different foci, as the former refers to expectations about all members of a social category whereas the latter refers to the organizationspecific expectations of a mnemonic community.

The concept of historical imperative suggests an understanding of organizational engagement with history that departs from prevailing views in organizational research of history as path dependency (e.g., Kimberly \& Bouchikhi, 1995) or a rhetorical strategic construction (e.g., Suddaby et al., 2010). It acknowledges instead that history is periodically reconstructed and used in light of present-day concerns (e.g., task goals), but at the same time underlines how this reconstruction is bound by the material memory that it draws upon and the mnemonic practices and expectations of relevant audiences (see also Sasaki et al., 2019). Thus, although the historical imperative we describe reflects the "burden of history," it does not do so in a deterministic way. It guides organizational action to be both historically informed and responsive to current strategic concerns.

It could be argued that, together, the three modes we have observed contribute to stabilize the expectations of the mnemonic community, reinforce its practices, and gradually extend its boundaries. Not only does identity stewardship motivate members to maintain those features that the community understands as "tradition," but it also helps perpetuate the tradition 
by guiding innovation to conform with it. Similarly, identity evangelizing valorizes the past by keeping it both focal (in attention) and positively valued to excite potential new community members, but it also offers the rest of the community opportunities to reaffirm their belongingness through ritualistic participation in commemorative events that consolidate collective memory. Finally, whereas heritage mining addresses a broad audience, the actions it inspires contribute to enrich the pool of resources available even for core community members to symbolically express their identification.

These observations shed light into the active role that organizations play in the maintenance of the mnemonic communities that revolve around them. These communities constitute important market segments for products that acquire special value by being symbolically linked to the organizational history. In this respect, the three modes we have observed complement one another to the extent that, when directed externally, identity evangelizing ultimately aims at enhancing the demand and willingness to pay for products that are consistent with the tradition (resulting from identity stewardship) or allude to a unique and significant past (heritage mining). Indeed, many informants drew attention to the increasing efforts and investments that their organizations made to liaise with these communities and support their collective practices.

Finally, it could be argued that mnemonic communities present a boundary condition of our study, and that our model pertains only to organizations with iconic products and brands. In less "glamorous" organizations, producing more mundane objects or characterized by less illustrious histories-one could argue- -historical artifacts will neither be preserved nor become part of mnemonic practices. This is an empirical question that may be addressed by future research. We do not deny that organizations that are highly valued and celebrated by external constituencies may be more likely to engage in the processes we described. However, while our theoretical explanation assumes the particular significance of the organization for a mnemonic community as an important boundary condition, it does not require the boundaries of the mnemonic community to extend beyond the organization. Nor does it require that mnemonic practices occur in museum facilities. Even in less glamorous organizations, the practices we described could unfold around historical objects, to the extent that their members-or even some of them-interpret these objects as identity markers, symbols of essential qualities, or valuable resources to inspire and enrich novel action.

\section{REFERENCES}

Albert, S., \& Whetten, D. A. 1985. Organizational identity. In L. L. Cummings \& B. M. Staw (Eds.), Research in organizational behavior, vol. 7: 263-295. Greenwich, CT: JAI Press.

Anteby, M., \& Molnar, V. 2012. Collective memory meets organizational identity: Remembering to forget in a firm's rhetorical history. Academy of Management Journal, 55: 515-540.

Ashforth, B. E., \& Mael, F. 1989. Social identity theory and the organization. Academy of Management Review, 14: 20-39.

Assmann, J. 1995. Collective memory and cultural identity. New German Critique, NGC, 65: 125-133.

Bagozzi, R. P., Bergami, M., Marzocchi, G. L., \& Morandin, G. 2012. Customer-organization relationships: Development and test of a theory of extended identities. Journal of Applied Psychology, 97: 63-76.

Barthel, D. L. 1996. Historic preservation: Collective memory and historical identity. New Brunswick, NJ: Rutgers University Press.

Bennett, T. 1995. The birth of the museum: History, theory, politics. New York, NY: Routledge.

Boje, D. M. 1995. Stories of the storytelling organization: A postmodern analysis of Disney as "Tamara-Land." Academy of Management Journal, 38: 997-1035.

Brown, A. D. 2006. A narrative approach to collective identities. Journal of Management Studies, 43: 731753.

Charmaz, K. 2014. Constructing grounded theory. London, U.K.: SAGE.

Cialdini, R. B., Borden, R. J., Thorne, A., Walker, M. R., Freeman, S., \& Sloan, L. R. 1976. Basking in reflected glory: Three (football) field studies. Journal of Personality and Social Psychology, 34: 366-375.

Corbin, J., \& Strauss, A. 1990. Grounded theory research: Procedures, canons, and evaluative criteria. Qualitative Sociology, 13: 3-21.

Corley, K. G., \& Gioia, D. A. 2004. Identity ambiguity and change in the wake of a corporate spin-off. Administrative Science Quarterly, 49: 173-208.

Cornelissen, J. P. 2006. Metaphor and the dynamics of knowledge in organization theory: A case study of the organizational identity metaphor. Journal of Management Studies, 43: 683-709.

Cox, J., \& Stromquist, S. (Eds.). 1998. Contesting the master narrative: Essays in social history. Iowa City, IA: University of Iowa Press.

De Massis, A., Kotlar, J., Frattini, F., Messeni, A., \& Wright, M. 2016. Innovation through tradition: Lessons from innovative family businesses and directions for future 
research. Academy of Management Perspectives, 30: 93-116.

Danilov, V. 1992. A planning guide for corporate museums, galleries and visitor centers. Westport, CT: Greenwood Press.

Dukerich, J. M., Golden, B. R., \& Shortell, S. M. 2002. Beauty is in the eye of the beholder: The impact of organizational identification, identity, and image on the cooperative behaviors of physicians. Administrative Science Quarterly, 47: 507-533.

Dumiak, M. 2006, June 12. Mercedes' monument to motion. Fortune: 17.

Duncan, C. 1991. Art museums and the ritual of citizenship. In I. Karp \& S. D. Lavine (Eds.), Exhibiting cultures: The poetics and politics of museum display. Washington, DC: Smithsonian Institution Press.

Dutton, J. E., \& Dukerich, J. M. 1991. Keeping an eye on the mirror: Image and identity in organizational adaptation. Academy of Management Journal, 34: 517-554.

Eisenhardt, K. M., \& Graebner, M. E. 2007. Theory building from cases: Opportunities and challenges. Academy of Management Journal, 50: 25-32.

Elsbach, K. D., Barr, P. S., \& Hargadon, A. B. 2005. Identifying situated cognition in organizations. Organization Science, 16: 422-433.

Flaherty, M. G., \& Fine, G. A. 2001. Present, past, and future. Time \& Society, 10: 147-161.

Foster, W. M., Coraiola, D. M., Suddaby, R., Kroezen, J., \& Chandler, D. 2016. The strategic use of historical narratives: A theoretical framework. Business History, 59: $1-25$.

Foster, W. M., Suddaby, R., Minkus, A., \& Wiebe, E. 2011. History as social memory assets: The example of Tim Hortons. Management \& Organizational History, 6: 101-120.

Gioia, D. A., Corley, K. G., \& Fabbri, T. 2002. Revisiting the past (while thinking in the future perfect tense). Journal of Organizational Change Management, 15: 622-634.

Gioia, D. A., Patvardhan, S. D., Hamilton, A. L., \& Corley, K. G. 2013. Organizational identity formation and change. Academy of Management Annals, 7: 123193.

Gioia, D. A., Price, K. N., Hamilton, A. L., \& Thomas, J. B. 2010. Forging an identity: An insider-outsider study of processes involved in the formation of organizational identity. Administrative Science Quarterly, 55: 1-46.

Gioia, D. A., Schultz, M., \& Corley, K. G. 2000. Organizational identity, image, and adaptive instability. Academy of Management Review, 25: 63-81.
Glynn, M. A. 2000. When cymbals become symbols: Conflict over organizational identity within a symphony orchestra. Organization Science, 11: 285-298.

Graebner, M. E., Martin, J. A., \& Roundy, P. T. 2012. Qualitative data: Cooking without a recipe. Strategic Organization, 10: 276-284.

Halbwachs, M. 1992. On collective memory. Chicago, IL: University of Chicago Press. (Original work published 1925)

Hargadon, A., \& Sutton, R. I. 1997. Technology brokering and innovation in a product development firm. $\boldsymbol{A d}$ ministrative Science Quarterly, 42: 716-749.

Harquail, C. V., \& Wilcox-King, A. 2010. Construing organizational identity: The role of embodied cognition. Organization Studies, 31: 1619-1648.

Hatch, M. J., \& Schultz, M. 2017. Toward a theory of using history authentically: Historicizing in the Carlsberg Group. Administrative Science Quarterly: 62: 657697.

Howard-Grenville, J., Metzger, M. L., \& Meyer, A. D. 2013. Rekindling the flame: Processes of identity resurrection. Academy of Management Journal, 56: 113-136.

Hsu, G., \& Hannan, M. T. 2005. Identities, genres, and organizational forms. Organization Science, 16: 474490.

Humphreys, M., \& Brown, A. D. 2002. Narratives of organizational identity and identification: A case study of hegemony and resistance. Organization Studies, 23: 421-447.

Kaplan, S., \& Orlikowski, W. J. 2013. Temporal work in strategy making. Organization Science, 24: 965-995.

Kimberly, J. R., \& Bouchikhi, H. 1995. The dynamics of organizational development and change: How the past shapes the present and constrains the future. Organization Science, 6: 9-18.

Kjærgaard, A., Morsing, M., \& Ravasi, D. 2011. Mediating identity: A study of media influence on organizational identity construction in a celebrity firm. Journal of Management Studies, 48: 514-543.

Kunisch, S., Bartunek, J. M., Mueller, J., \& Huy, Q. N. 2017. Time in strategic change research. Academy of Management Annals, 11: 1005-1064.

Langley, A. 1999. Strategies for theorizing from process data. Academy of Management Review, 24: 691-710.

Lincoln, Y., \& Guba, E. 1985. Naturalistic Inquiry. Beverly Hills, CA: Sage Publications.

Locke, K. 2001. Grounded theory in management research. London, U.K.: SAGE.

Lowenthal, D. 1985. The Past is a Foreign Country. Cambridge, U.K.: Cambridge University Press. 
Maclean, M., Harvey, C., Sillince, J. A., \& Golant, B. D. 2014. Living up to the past? Ideological sensemaking in organizational transition. Organization, 21: 543-567.

Mael, F., \& Ashforth, B. E. 1992. Alumni and their alma mater: A partial test of the reformulated model of organizational identification. Journal of Organizational Behavior, 13: 103-123.

Manning, P. K. 1979. Metaphors of the field: Varieties of organizational discourse. Administrative Science Quarterly, 24: 660-671.

Martin, J., Feldman, M. S., Hatch, M. J., \& Simkin, S. B. 1983. The uniqueness paradox in organizational stories. Administrative Science Quarterly, 28: 438-453.

Mead, G. H. 1932. The philosophy of the present [PDF file]. London, U.K.: Open Court. Retrieved from https://ia802500. us.archive.org/14/items/philosophyofthep032111mbp/ philosophyofthep032111mbp.pdf

Miles, M. B., \& Huberman, M. A. 1984. Qualitative data analysis. Thousand Oaks, CA: SAGE.

Misztal, B. 2003. Theories of social remembering. London, U.K.: McGraw-Hill Education.

Moorman, C., \& Miner, A. S. 1998. Organizational improvisation and organizational memory. Academy of Management Review, 23: 698-723.

Musson, G., \& Tietze, S. 2004. Places and spaces: The role of metonymy in organizational talk. Journal of Management Studies, 41: 1301-1323.

Navis, C., \& Glynn, M. A. 2010. How new market categories emerge: Temporal dynamics of legitimacy, identity, and entrepreneurship in satellite radio, 1990-2005. Administrative Science Quarterly, 55: $439-471$.

Nissley, N., \& Casey, A. 2002. The politics of the exhibition: Viewing corporate museums through the paradigmatic lens of organizational memory. British Journal of Management, 13: 35-45.

Nora, P. 1989. Between memory and history: Les lieux de mémoire. Representations, 26: 7-24.

Olick, J. K. 1999. Collective memory: Two cultures. Sociological Theory, 17: 333-348.

Olick, J. K., \& Levy, D. 1997. Collective memory and cultural constraint: Holocaust myth and rationality in German politics. American Sociological Review, 62: 921-936.

Olick, J. K., \& Robbins, J. 1998. Social memory studies: From "collective memory" to the historical sociology of mnemonic practices. Annual Review of Sociology, 24: $105-140$.

Ooi, C. S. 2002. Persuasive histories: Decentering, recentering and the emotional crafting of the past. Journal of Organizational Change Management, 15: 606-621.
Radley, A. 1990. Artefacts, memory and a sense of the past. In D. Middleton \& D. Edwards (Eds.), Collective remembering (2nd ed.): 46-59. Newbury Park, CA: SAGE.

Ravasi, D., \& Schultz, M. 2006. Responding to organizational identity threats: Exploring the role of organizational culture. Academy of Management Journal, 49: 433-458.

Rindova, V. P., Dalpiaz, E., \& Ravasi, D. 2011. A cultural quest: A study of organizational use of new cultural resources in strategy formation. Organization Science, 22: 413-431.

Rowlinson, M., \& Hassard, J. 1993. The invention of corporate culture: A history of the histories of Cadbury. Human Relations, 46: 299-326.

Rowlinson, M., Casey, A., Hansen, P. H., \& Mills, A. J. 2014. Narratives and memory in organizations. Organization, 21: 441-446.

Sandberg, J., Loacker, B., \& Alvesson, M. 2015. Conceptions of process in organization and management. In R. Garud, B. Simpson, A. Langley, \& H. Tsoukas (Eds.), The emergence of novelty in organizations: 305-318. Oxford, U.K.: Oxford University Press.

Sasaki, I., Kotlar, J., Ravasi, D., \& Vaara, E. 2019. Dealing with revered past: Historical identity statements and strategic change in Japanese family firms. Strategic Management Journal. Published online ahead of print. doi: 10.1002/smj.3065.

Schultz, M. 2016. Organizational identity change and temporality. In M. Pratt, M. Schultz, B. E. Ashforth, \& D. Ravasi (Eds.), The Oxford handbook on organizational identity: 93-105. Oxford: U.K.: Oxford University Press.

Schultz, M., \& Hernes, T. 2013. A temporal perspective on organizational identity. Organization Science, 24: 1-21.

Schultz, M., \& Hernes, T. 2019. Temporal interplay between strategy and identity: Punctuated, subsumed, and sustained modes. Strategic Organization. Published online ahead of print. doi: 10.1177/1476127019843834.

Schumpeter. 2012, November 17. Museums of mammon [Blog post]. Economist. Retrieved from https://www. economist.com/business/2012/11/17/museums-ofmammon

Schwartz, B. 1982. The social context of commemoration: A study in collective memory. Social Forces, 61: 374-402.

Schwartz, B. 2000. Abraham Lincoln and the forge of national memory. Chicago, IL: University of Chicago Press.

Starbuck, W. H., \& Milliken, F. J. 1988. Executives' perceptual filters: What they notice and how they make sense. In D. Hambrick (Ed.), The executive effect: Concepts and methods for studying top managers: 35-65. Greenwich, CT: JAI Press. 
Strauss, A., \& Corbin, J. 1998. Basics of qualitative research: Techniques and procedures for developing grounded theory. Thousand Oaks, CA: SAGE.

Suddaby, R. 2006. From the editors: What grounded theory is not. Academy of Management Journal, 49: 633-642.

Suddaby, R., Foster, W. M., \& Quinn Trank, C. 2010. Rhetorical history as a source of competitive advantage. Advances in Strategic Management, 27: 147-173.

Suddaby, R., Foster, W. M., \& Quinn Trank, C. 2016. Remembering: Rhetorical history as identity-work. In M. G. Pratt, M. Schultz, B. E. Ashforth, \& D. Ravasi (Eds.), The Oxford handbook of organizational identity: 297-316. New York, NY: Oxford University Press.

Sydow, J., Schreyögg, G., \& Koch, J. 2009. Organizational path dependence: Opening the black box. Academy of Management Review, 34: 689-709.

Wagner-Pacifici, R., \& Schwartz, B. 1991. The Vietnam Veterans Memorial: Commemorating a difficult past. American Journal of Sociology, 97: 376-420.

Walsh, J. P., \& Ungson, G. R. 1991. Organizational memory. Academy of Management Review, 16: 57-91.

Wertsch, J. V. 2002. Voices of collective remembering. Cambridge, U.K.: Cambridge University Press.

Whetten, D. A. 2006. Albert and Whetten revisited: Strengthening the concept of organizational identity. Journal of Management Inquiry, 15: 219-234.

Yanow, D. 1998. Space stories: Studying museum buildings as organizational spaces while reflecting on interpretative methods and their narration. Journal of Management Inquiry, 7: 215-239.

Ybema, S. 2010. Talk of change: Temporal contrasts and collective identities. Organization Studies, 31:481-503.

Yin, R. K. 1994. Case study research. Beverly Hills, CA: SAGE.

Zerubavel, E. 1996. Social memories: Steps to a sociology of the past. Qualitative Sociology, 19: 283-299.

Zerubavel, E. 2003. Calendars and history: A comparative study of the social organization of national memory. In
J. K. Olick (Ed.), States of memory: Continuities, conflicts, and transformations in national retrospection: 315-337. Durham, NC: Duke University Press.

Zolberg, V. 1996. Museums as contested sites of remembrance: The Enola Gay affair. In S. Macdonald \& G. Fyfe (Eds.), Theorizing museums: Representing identity and diversity in a changing world: 69-82. Oxford, U.K.: Blackwell.

Zuckerman, E. W. 1999. The categorical imperative: Securities analysts and the illegitimacy discount. American Sociological Review, 104: 1398-1438.

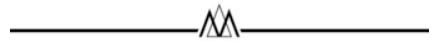

Davide Ravasi (d.ravasi@ucl.ac.uk) is professor of strategy and entrepreneurship at the UCL School of Management, University College London. His research examines strategic and organizational changes, particularly changes that challenge or otherwise affect the organizational culture or identity. He is interested more generally in sociocognitive processes shaping entrepreneurship, design, and innovation.

Violina P. Rindova (rindova@marshall.usc.edu) is a professor of strategy and the Captain Henry W. Simonsen Chair in Strategic Entrepreneurship at the Marshall School of Business, University of Southern California. Her research focuses on the sociocognitive and cultural processes through which firms create value, new market opportunities, and positions of advantage.

Ileana Stigliani (i.stigliani@imperial.ac.uk) is an associate professor in the management department of Imperial College Business School, London. She received her PhD in management from Bocconi University. Her research pertains to materiality and meaning creation. She studies how material artifacts and practices influence cognitive processes -including sensemaking and sensegiving, and perceptions of organizational and professional identities-within organizations. 